\title{
LA INDUSTRIA PESQUERA Y CONSERVERA PÚNICO-GADITANA: BALANCE DE LA INVESTIGACIÓN. NUEVAS PERSPECTIVAS
}

\author{
PUNIC FISHING INDUSTRIES IN CADIZ: A STATE OF ART \\ AND NEW RESEARCH PERSPECTIVES
}

\author{
por \\ GREGORIO DE FRUTOS REYES* y ÁNGEL MUÑOZ VICENTE**
}

RESUMEN En este trabajo pretendemos presentar las últimas novedades que recoge la arqueología sobre el tema en la ciudad de Cádiz. Son de gran relevancia, puesto que retrotraen los orígenes de las actividades industriales, hasta el s. VI a.C.

Por otra parte, en esta publicación tratamos de hacer un análisis histórico evolutivo, bajo la perspectiva de la producción, y de la importancia del comercio. Proponemos diferentes hipótesis y nuevas propuestas basadas tanto en las fuentes literarias como en las contribuciones arqueológicas de los últimos quince años.

ABSTRACT In this work, we intend to present the last novelties that archaeology presents on the topic of discussion in the city of Cádiz. These are of relevant importance, since they date back the origins of theol industrial activites to, at least, the $6^{\mathrm{m}}$ century B.C.

On the other hand, in this publication we attempt to accomplish a historical-evolutive trial, in the perspective of the production as well as of the perspective of the production as well as of the importante of comerce. We propose various hypothesis and new positions based an the literary sources as well as on the plan of the archaeologic contributions of the last fifteen years

\section{1.- INTRODUCCIÓN}

Hace algunos años, en 1987, iniciamos una línea de trabajo conjunta sobre establecimientos industriales dedicados a la elaboración de productos derivados de la pesca en época prerromana. La idea surgió al disponer

\footnotetext{
* Área de Historia Antigua. Departamento de Historia de la Antigüedad, Arte, Geografía Física y Antropología. Universidad de Huelva

** Delegación Provincial de Cultura de la Junta de Andalucía en Cádiz. Departamento de Conservación.
} 
de una información, en esos momentos inédita, de diversos trabajos arqueológicos de urgencia efectuados en el área de la Bahía de Cádiz. Por un lado, en 1980, uno de los que suscribe codirigió las excavaciones de una factoría de salazones prerromana en Las Redes, en el Puerto de Santa María, documentándose una actividad industrial desde el siglo V a.C. hasta los inicios del siglo II a.C. (Frutos, Chic, Berriatúa 1988: 295-306; Muñoz, Frutos, Berriatúa 1988: 490-496). Por otro lado las numerosas intervenciones en solares de la ciudad de Cádiz, ya desde 1980, en el control de obras de nueva construcción, ponían al descubierto numerosos restos arqueológicos consistentes sobre todo en necrópolis de diversa cronología. En 1984, unas excavaciones en la necrópolis púnica, en el sector de la plaza de Asdrúbal, suministraba los primeros datos de industrias de salazones en la ciudad. En concreto se trataba de una factoría, muy alterada por enterramientos, que comenzaba su actividad en el siglo V a.C. (Muñoz, Frutos, Berriatúa 1988: 488). Algo más tarde, en 1986, en un solar próximo al anterior, en la Avenida de Andalucía, de nuevo surgían restos de industrias de este tipo, documentandose diversas estancias de características similares a la anterior (Muñoz, Frutos, Berriatúa 1988: 489-490). En ese mismo año en la confluencia de las avenidas García de Sola y de Portugal se localizaban los restos de una pileta de planta cuadrada perteneciente a otro enclave de estas características (Muñoz, Frutos, Berriatúa 1988: 490).

Con esta documentación, en noviembre de 1987 presentamos en el I Congreso Internacional del Estrecho de Gibraltar una comunicación titulada "Contribución a los orígenes y difusión comercial de la industria pesquera y conservera gaditana a través de las recientes aportaciones de las factorías de salazones de la Bahía de Cádiz", donde describíamos las factorías excavadas, analizábamos los materiales anfóricos y extraíamos unas conclusiones sobre el origen y comercialización de estos productos (Muñoz, Frutos, Berriatúa 1988: 487-508).

En diciembre de ese mismo año, uno de los que suscribe iniciaba unas excavaciones arqueológicas de urgencia en los hornos púnicos de Torre Alta, en San Fernando, donde se excavaron dos estructuras de hornos destinados a la elaboración de envases (ánforas) para contener productos derivados de la pesca, así como un variado conjunto de marcas impresas que nos informaban de la dinámica de la comercialización y de los procedimientos político-económicos de esta actividad industrial y comercial (Perdigones, Muñoz 1990: 106-112; Muñoz 1993: 328)

Con esta información presentamos al I Congreso de Arqueología del Suroeste, celebrado en Huelva en 1994, una comunicación titulada "Hornos púnicos de Torre Alta (San Fernando, Cádiz)", dónde exponíamos un ensayo de interpretación de la actividad comercial en época prerromana (Frutos, Muñoz 1994: 393-414).

Por estos años otros trabajos en el área de El Puerto de Santa María en enclaves similares, ponían de manifiesto la existencia de una industria de pequeña escala, de carácter eminentemente familiar, localizándose en prospecciones superficiales más de una veintena de pequeñas factorías con cronologías que arrancan del siglo V a.C. y perduran hasta el siglo III a.C.(Ruiz 1987: 101-105).

A finales de 1988, en la calle Dr. Gregorio Marañón en la ciudad de Cádiz se iniciaba una intervención arqueológica de urgencia, localizándose los restos de parte de una factoría de salazones compuesta por varios pavimentos superpuestos así como una pileta y un área de vertido de material desechable. Lo interesante de este enclave radica en ser un ejemplo de factoría de salazones de transición de época tardopúnica a época romana (Blanco 1991: 87-91)

El presente trabajo tiene por finalidad, pues, presentar de manera global los resultados de nuestra investigación en el campo de la indüstria pesquera y conservera gaditana en época prerromana. En él analizaremos, en síntesis, los datos arqueológicos describiendo las factorías de salazones y la única alfarería, hasta hoy conocida, que estuvo dedicada a la elaboración de envases destinados a contener dichos productos. El análisis de los materiales, en su mayoría ánforas, así como el estudio de los textos escritos nos permitirán aproximarnos a la dinámica de su elaboración, comercialización y sus procedimientos político-económicos (fig. 1). 


\section{2.- LOS DATOS ARQUEOLÓGICOS}

\subsection{Las factorías de salazones}

Los autores griegos nos hablan de cómo ya en el siglo $\mathrm{V}$ a.C. las conservas gaditanas eran conocidas en la parte oriental del Mediterráneo, donde competían con las del área del Egeo (testimonios de Eupolis). Estas referencias continúan en el siglo IV a.C. y muestra de ello son los textos de Nicóstrato, Antífanes o el Pseudo Aristóteles (Chic, Frutos 1984: 220 y ss; Frutos 1987: 374 y ss; Frutos 1991; Muñoz, Frutos, Berriatúa 1988: 502-508; Curtis 1991: 46-64). Estas industrias del área gaditana surgen como consecuencia del alto potencial pesquero de la zona. Concretamente a mediados del mes de junio se produce la emigración que todos los años realizan los atunes al Mediterráneo para llevar a cabo su reproducción. Cuando pasan el Estrecho de Gibraltar, estos túnidos, gruesos y con sus ventrescas repletas de huevas, son esperados y capturados, tal y como nos refiere el Ps. Aristóteles. Cuando termina el desove en el mes de julio, regresan al Atlántico, donde a su paso por el Estrecho son de nuevo capturados, delgados y famélicos, aunque las salsas y salazones extraídas de ellos no tendrán la exquisitez y calidad de las anteriores. Estos intereses pesqueros generaron la instalación de almadrabas y factorías a lo largo de las costas del Estrecho de Gibraltar.

Son múltiples los enclaves industriales de esta índole documentados por las costas atlántica y mediterránea, correspondiendo un amplio grupo al litoral gaditano. Sin embargo, la cronología de la casi totalidad de estos enclaves nos sitúa en época romana (Ponsich, Tarradell 1965; Ponsich 1988).

Hoy por hoy las factorías más antiguas documentadas se ubican en las costas gaditana y portuense. Su cronología se remonta al siglo $\mathrm{V}$ a.C., coincidiendo con las primeras noticias escritas al respecto. Esta actividad generó un comercio de salazones de amplio radio, comercio que, incluso, generó actividades de contrabando, que nos permiten intuir que eran productos caros y difíciles de adquirir, pues como escribía Nicóstrato hacia el 380 a.C. "...que se abandone al placer del filete de pescado de Bizancio y que se introduzca furtivamente hipogastrio de Gadira." (Nicostr., Com. C.A.F. ed. T. Kock).

\subsubsection{La factoría de Las Redes. El Puerto de Santa María. (Cádiz)}

Se ubicaba en la playa de Fuentebravía, en la línea costera que discurre entre las poblaciones de El Puerto y Rota.

La factoría estaba asentada sobre una duna muerta de forma circular cubierta por pinos y matorral de monte bajo, con una altitud de $44 \mathrm{~m}$ sobre el actual nivel del mar.

Presenta planta de forma casi cuadrada, cuyas dimensiones eran de $10,70 \times 10,60 \mathrm{~m}$, en su momento de esplendor (fig. 2). A lo largo de su existencia se realizaron en el inmueble una serie de modificaciones en las que siempre se aprovecharon los muros y construcciones de la fase anterior. Los muros están formados por piedras de la zona de formas irregulares unidos con argamasa de cal y pequeños guijarros.

El conjunto de la factoría está formado por cinco dependencias: la número 1, según los hallazgos y la composición del suelo -tierras oscuras producto de la descomposición de materias orgánicas y de la utilización de hogares- nos hace pensar que hubiera sido probablemente destinada a la transformación industrial del pescado (garum). La habitación nำ2, de la misma longitud, pero más estrecha que la anterior, tenía su suelo inclinado hacia el mar, cubierto por un pavimento realizado a base de pequeños guijarros mezclados con cal y cerámicas trituradas. Estaría destinada al almacenamiento y limpieza del pescado. La dependencia no 3 podría ser la entrada principal de la factoría, por la cual se introducía el pescado o se expedían las ánforas que contenían las salazones y el garum. La no 4 se utilizaría para el almacenamiento de los instrumentos utilizados para la pesca y funcionamiento de la factoría. Los materiales localizados 
corresponden en su mayor parte a anzuelos, agujas para coser redes, pesas, etc. La estancia no 5 , por último, con sus piletas bien conservadas, estaría destinada a la maceración del pescado.

Se distinguieron cuatro fases de ocupación correspondiendo el primer momento (Fase I) al periodo comprendido entre 430-325 a.C. aproximadamente. Constituye la época de esplendor o mayor actividad de la factoría, ya que en estos momentos es cuando el enclave ocupa mayor superficie. Igualmente a esta fase corresponde más del $46 \%$ del total del material estudiado.

La Fase II se enmarca cronológicamente entre el año 325 a.C. y el 275 a.C., observándose desde la mitad de este periodo un decaimiento de las actividades.

La Fase III, fechada entre el 275 y el 200 a.C., corresponde al periodo final y de decadencia de la factoría, manifestándose en un progresivo descenso de la actividad y en una reducción de la extensión de la misma. El material arqueológico en este periodo no llega al $15 \%$.

Por último, la Fase IV, corresponde, tras un largo hiatus cronológico, al siglo XVII, cuando en el lugar se sitúa una pequeña casa de pescadores, que para su construcción aprovecha piedra y muros antiguos de la factoría.

\subsubsection{La factoría de la Plaza de Asdrúbal. Cádiz}

Esta factoría se encontraba ubicada en la plaza de Asdrúbal, en una zona próxima al talud que mira al Océano, a unos $11 \mathrm{~m}$ sobre el nivel del mar.

Su excavación se efectuó en dos fases, la primera en 1984, al ser necesario documentar el subsuelo en esta zona debido a la próxima construcción de un edificio de nueva planta. La segunda, en 1985, al existir otro proyecto de obras, que igualmente hacía necesaria la investigación arqueológica previa al inicio de los movimientos de tierras. Los resultados de ambas campañas fueron muy similares. Esta zona fue utilizada también como necrópolis lo que dificultó parcialmente la delimitación de estructuras y pavimentos, que en unos casos se superponían a las tumbas y en otros eran cortados por las fosas de éstas. No se pudo determinar ni la extensión ni el número de dependencias de la factoría ya que las estructuras localizadas correspondieron a zonas de vertidos de desechos y a algún que otro pavimento muy deteriorado (fig. 3)

En líneas generales la factoría comienza su actividad en la primera mitad del siglo $\mathrm{V}$ a.C. A esta primera fase que corresponde a su época de esplendor y que cronológicamente se extiende hasta finales de la misma centuria, corresponden varias fosas con materiales de desechos (basureros) entre los que se localizaron tanto fragmentos de contenedores y vajilla relacionada con esta actividad (ánforas, platos con engobe rojo, etc.) como útiles para la pesca (anzuelos, agujas), así como abundante material malacológico y restos de peces.

Desde los inicios del siglo IV a.C. el porcentaje de materiales desciende, lo que debe indicarnos un decaimiento de la actividad, circunstancia que continuó hasta el último tercio del siglo III a.C., donde asistimos a una fuerte reactivación de los trabajos (figs. 7-9). A este periodo que prácticamente dura hasta los inicios del siglo II a.C., corresponden varios suelos apisonados de piedras y cerámicas, destinados, al igual que la estancia no 2 de la factoría de Las Redes, a la limpieza y almacenamiento del pescado.

En el siglo II a.C., se observa otra fase de decaimiento de la factoría, perdurando, sin solución de continuidad, hasta la primera mitad del siglo I a.C. En este periodo se documenta un recinto rectangular con muros de sillarejos y piedras planas irregulares unidas con arcilla. 


\subsubsection{La factoría de la Avenida de Andalucía el a Ciudad de Santander. Cádiz}

Se encontraba situada en la actual Avenida de Andalucía, muy próxima a la anterior y al igual que ella, dentro del territorio ocupado por la mayor de las islas (Kotinoussa) a las que hacen referencia los autores antiguos (sobre todo Plinio).

La excavación se efectuó en 1986, y en líneas generales los resultados fueron muy similares a los de la Plaza de Asdrúbal.

El comienzo de la actividad industrial se inicia en los comienzos del siglo $\mathrm{V}$ a.C., correspondiendo a este periodo una gran fosa con material de desecho, así como un suelo de piedras de pequeñas dimensiones.

En los comienzos del siglo IV a.C. asistimos a un periodo de decaimiento, que se prolonga, al igual que en la Plaza de Asdrúbal, hasta el último tercio del siglo III a.C. De estos momentos no se documentaron estructuras edilicias, sólo un nivel de arenas pardas compactas con escaso material cerámico.

No será hasta la llegada de los Bárcidas, cuando se vuelva a producir un resurgimiento de las actividades. A esta fase corresponden varios pavimentos de piedras y cerámicas localizados a lo largo de la superficie excavada.

En el siglo II a.C. la factoría mantiene un buen nivel de producción, si bien se asiste, al igual que en la de la cercana Plaza de Asdrúbal, al inicio de su decadencia definitiva. De este periodo son algunos muros de sillarejos y arcilla y los restos de una pileta.

\subsubsection{La factoría de la Avda. de García de Sola ela Avda. De Portugal (Cádiz)}

$\mathrm{Al}$ realizarse obras de instalación de una nueva red de alcantarillado en los Extramuros de la ciudad de Cádiz, se localizaron, independientemente de numerosos enterramientos como es habitual en esta zona, los restos de una pileta para la salazón del pescado. Tenía planta cuadrada con muros de sillares de piedra ostionera y revestimiento de mortero de cal y arena.

Los materiales localizados fueron muy escasos y poco significativos, pudiéndose fechar la estructura en el siglo IV a.C. gracias al hallazgo en su entorno de un ánfora casi completa de nuestra forma E-1 (Muñoz 1987: 471 y ss).

\subsubsection{La factoría de la C/ Dr. Gregorio Marañón (Cádiz)}

Las intervenciones arqueológicas de urgencia de carácter urbano tienen la limitación de ceñirse exclusivamente al suelo disponible objeto de una actuación urbanística. Así la investigación arqueológica se ve reducida a un espacio concreto y limitado que no es posible ampliar en la mayoría de los casos debido a la existencia de inmuebles en el entorno. Esto impide, en un gran porcentaje, documentar en su totalidad unidades arqueológicas constructivas, lo que mermará en gran medida el conocimiento global de la ocupación espacial de un inmueble arqueológico, al menos a corto plazo.

Este es el caso de la factoría de la C/ Dr. Gregorio Marañón, que al igual que las anteriores de la ciudad de Cádiz, únicamente han podido documentarse de forma parcial.

Estaba ubicada en el Casco Histórico de la ciudad de Cádiz, dentro del territorio ocupado por la menor de las islas (Erytheia) a que hace referencia el texto de Plinio. Su situación dentro de esta zona corresponde a las proximidades de la playa de La Caleta, en las cercanías del canal marino que dividía en dos esta parte de la ciudad que hoy conocemos. 
La intervención arqueológica se llevó a cabo en 1988, siendo gestionada y financiada por la Delegación provincial de Cultura de la Junta de Andalucía en Cádiz y dirigida por D. Francisco J. Blanco Jiménez (Blanco 1991: 78-81)

Las estructuras documentadas en esta intervención consistieron en varios pavimentos superpuestos, una pileta de salazón de pescado y una zona de vertido de materiales de desecho.

Por lo que se refiere a los pavimentos se distribuyen en número de tres, de manera superpuesta, lo cual nos indica varias fases en las que la factoría estuvo funcionando en mayor o menor intensidad.

El suelo de época más reciente está realizado a base de un mortero de cal y argamasa, conchas trituradas, restos óseos y algunos fragmentos cerámicos. Posiblemente se trate de una reparación de otro suelo anterior, ya que sólo aparece en un pequeño sector en el lado oeste del solar.

El segundo pavimento se extiende por todo el sector noroeste del solar, estando realizado a base de opus signinum. Su excavador lo fecha en la primera mitad del siglo I d.C.

El pavimento inferior está igualmente ejecutado a base de opus signinum. Por los materiales de la cimentación parece corresponder al siglo I a.C., siendo muy alterado cuando la construcción del anterior.

Sobre el primer pavimento aparecen algunas alineaciones de piedra ostionera, no pudiéndose determinar los límites ni la planta de este sector de la factoría.

En el pavimento segundo se localizaron, embutidos en él, las mitades inferiores de cuatro ánforas, que parecen pertenecer a tipos datables en la primera mitad del siglo I d.C.

Por lo que respecta a la pileta presenta igualmente tres momentos de uso que coinciden con las fases determinadas en los pavimentos. Era de planta rectangular de 4,70 x 1,37 m, teniendo una profundidad máxima conservada de $0,90 \mathrm{~m}$.

Los muros estaban realizados a base de sillarejos y sillares de piedra arenisca trabada con arcilla rojiza y recubiertos con una fina capa de mortero de cal y arena. En la unión del pavimento con las paredes presenta un cordón hidráulico de unos $5 \mathrm{~cm}$. Los materiales de cimentación del pavimento de la misma ofrecen, al igual que el tercer suelo, una cronología del siglo I a.C.

Por lo que se refiere a la zona de vertidos, se localizó en el sector sur del solar, teniendo una longitud de 4,78 $\mathrm{m}$ y una anchura máxima de $3,50 \mathrm{~m}$. Tiene planta de forma piriforme o cónica con una inclinación de norte a sur de unos $30^{\circ}$ aproximadamente (fig. 4). La estratigrafía mostró varias capas de vertidos de materiales desechables con una secuencia formada por los siguientes niveles:

1.- Tierras de coloración castaña que representan el abandono de la zona como escombrera. Cronología de la $1^{\text {a }}$ mitad del siglo I d.C. Potencia $50 \mathrm{~cm}$.

2.- Última capa de vertidos. Se documentan algunos fragmentos de ánforas $\mathrm{C} 2 \mathrm{~b}$ junto a estucos, restos de cenizas y arcilla requemada. Potencia $1,10 \mathrm{~m}$.

3.- Tierras rojizas anaranjadas, con muy pocos fragmentos cerámicos. Potencia $50 \mathrm{~cm}$.

4.- Tierras rojizas de naturaleza arcillosa con restos de carbón y numerosos fragmentos de ánforas $\mathrm{C} 2 \mathrm{~b}$ y Dr.1A. Potencia entre 37 y $49 \mathrm{cms}$ (fig. 10).

5.- Arena amarillenta con numerosos fragmentos de ánforas, algunos casi completos, correspondientes al tipo $\mathrm{C} 2 \mathrm{~b}$, con marcas impresas en cartelas rectangulares situadas en el cuerpo a la altura de las asas (fig. 10A). Algunos recipientes presentan fallos de cocción, lo que nos indica que esta factoría dispondría además de su propia alfarería para la elaboración de los envases contenedores de los productos derivados de la pesca. Este nivel corresponde al de mayor densidad e indica la fase de mayor actividad de la factoría.

Entre las estampillas localizadas en este vertedero están por un lado las de grafía tardo púnica, $b d a l H b t$, y por otros nombres impresos en caracteres latinos, mis.e; bar.t; balt y ta?, de los cuales bar.t y balt son claramente semitas (Muñoz 1993: 328; Ramon 1995: 252). 
2.1.6. Otros restos arqueológicos relacionados con actividades pesqueras: el solar del antiguo Teatro Andalucía (Cádiz)

Las recientes excavaciones arqueológicas de urgencia realizadas este año por la Delegación Provincial de Cultura bajo la dirección del arqueólogo D. Luis Cobos, en el antiguo solar del Teatro de Andalucía de Cádiz, situado paleotopográficamente hablando en el borde septentrional de la isla menor llamada Erytheia por los autores clásicos, junto al denominado canal Caleta-Bahía, que pudo constituir durante el Pleistoceno un antiguo cauce del río Guadalete, han puesto de relieve una actividad humana relacionada con la pesca en época fenicia arcaica. Se trata de una unidad estratigráfica donde se han localizado algunos fragmentos de ánforas fenicias del siglo VII a.C junto a abundante malacofauna y restos óseos de pescados.

Hacia el siglo III a.C., en este sector septentrional del borde del canal marino, se documentan unas fogatas excavadas en un nivel de arcillas rojizas, delimitadas algunas por pequeñas piedras. Los materiales arqueológicos localizados son fundamentalmente platos de pescado de engobe rojo, restos óseos de pescado y abundante malacofauna. Estamos ante una actividad humana no definida con claridad, pero si relacionada con pesquerías o actividades portuarias. Los fragmentos de ánforas Mañá-Pascual A4 en estos niveles feniciopúnicos, así como otros materiales anfóricos (importaciones de la costa catalana, cartaginesas y ebusitanas) abren la hipótesis de la existencia en las cercanías de una factoría de salazones de los siglos V-III a.C., sobre todo si tenemos en cuenta que en los niveles superiores se ha excavado una importante factoría romana con inicios de actividades en época republicana y abandono a principios del siglo $\mathrm{V} \mathrm{d.C.} \mathrm{(fig.} \mathrm{5).}$

\subsection{Las alfarerías}

\subsubsection{La alfarería de Torre Alta. San Fernando (Cádiz)}

El yacimiento se encuentra situado al noroeste de la ciudad de San Fernando, en una pequeña elevación del terreno en los inicios de la C/ Benjamín López. La primera intervención arqueológica se efectuó en los años 1987, y 1988 con el objeto de documentar el yacimiento, ya que la zona se veía afectada por la redacción del nuevo Plan General de Ordenación Urbana. La segunda intervención se está realizando cuando redactamos este artículo y tiene por finalidad la documentación total de la alfarería de cara a su conservación in situ para su puesta en valor y visita pública.

Las excavaciones de 1987 depararon el descubrimiento de dos estructuras de hornos de características constructivas similares, diferenciándose únicamente en el tamaño.

Ambos hornos presentan planta en forma de " $U$ " con los extremos algo cerrados, aunque el desplazamiento de las paredes próximas al corredor, en el caso del horno mayor, le dan en la actualidad un aspecto casi circular. Conservan el corredor de acceso, la cámara de combustión y la columna central. El suelo perforado o parrilla, en ambos casos, apareció desplomado en el interior de la cámara de combustión (fig. 6).

Para la construcción de estos hornos se excavaron dos grandes fosas en el terreno natural que se revistieron con sendos muros de tapial reforzados por adobes rectangulares, piedras y adobes dispuestos verticalmente en la mitad superior de gran parte de las paredes. Ambos hornos disponen de una columna central construida con tambores de piedra ostionera unidos con arcilla. La de mayores dimensiones conserva en la parte frontal al corredor el arranque de uno de los arcos que formaría la bóveda radial que sostendría la parrilla. Ésta se compondría de una falsa bóveda realizada con ladrillos plano-convexos unidos con arcilla.

Desconocemos en ambos hornos cómo serían las cámaras superiores o de cocción. Éstas, a juzgar por los ejemplos conocidos, estarían formadas por un muro cilíndrico rematado por una bóveda, que podría ser fija o móvil según la consistencia de los muros. El hecho de haber aparecido en el interior de los hornos 
numerosos fragmentos cerámicos nos hace pensar que, o bien que en ella también se procediera a la cocción de vasos cerámicos, o bien que éstos se cubrirían con una bóveda móvil realizada con fragmentos cerámicos, barro y ramas.

En estos hornos se fabricaron esencialmente ánforas, además de otros vasos menores (cuencos de diversos tipos, platos, ollas, tapaderas, tazas, lebrillos...) entre los que destacan cuatro formas locales de la cerámica de barniz negro tipo Campaniense A (formas 27,31,36 y 55 de Beltrán).

De los hallazgos proporcionados por este yacimiento, las marcas que presentan determinados ejemplares de ánforas y que más adelante analizaremos, constituyen, sin duda, un elemento de gran interés, puesto que nos dan claves y referencias para calibrar la importancia de la industria de salazones y salsas de pescado y su dinámica comercial. Los motivos figurativos que encierran estos timbres son los de la representación esquemática de Tanit, la roseta de ocho pétalos y diversas representaciones humanas portando peces (quizás atunes) o manipulando un recipiente de la forma documentada en los hornos. Es decir, muestran, diversos momentos del proceso de fabricación y envasado de las salazones y salsas de pescado (fig. 11).

Las excavaciones que en la actualidad se realizan no han documentado hasta la fecha nuevas estructuras edilicias. Sin embargo, se han localizado varias escombreras que están permitiendo afinar con mayor exactitud los límites cronológicos y fases de usos del complejo alfarero. En líneas generales el comienzo de la actividad industrial parece situarse en el siglo III a.C. sobre todo en su último tercio, perdurando durante una buena parte de la centuria siguiente. El elenco anfórico que publicamos con anterioridad no ha sufrido variaciones, ya que hasta la fecha el material localizado se encaja en los tipos definidos.

Es de destacar que en las zonas de vertidos excavadas se han localizado entre las cerámicas abundantes restos de malacofauna y peces (atunes, sepias...), lo que podría indicarnos que esta alfarería formase parte de un gran complejo industrial que dispondría igualmente de un sector dedicado a la elaboración de los productos derivados de la pesca.

\subsubsection{La alfarería de la C/ Tolosa Latour. Cádiz}

En las excavaciones de urgencia realizadas en 1987 en la C/Tolosa Latour, dentro del área de las necrópolis fenicia, púnica y romana, se documentó una fosa de vertido de material anfórico desechable compuesta por fragmentos de ánforas entre los que destacan un tercio superior con fallo de cochura de un recipiente de la forma Torre Alta 1A (fig. 10B), que más adelante analizaremos, así como un ejemplar fragmentario de la forma Torre Alta 1B. Las características de estos materiales nos indican la presencia en las inmediaciones de un alfar similar al anteriormente citado.

\subsubsection{Hallazgos alfareros en la Puntilla del Salado. Rota}

Otros hallazgos relacionados con la industria alfarera documentados en la provincia de Cádiz, son una serie de sellos, en forma de pequeños cuadrados de plomo, posiblemente para el estampillado de ánforas que representan el negativo de rosetas.

Estos materiales, documentados en una prospección superficial realizada en la década de los años cincuenta por $\mathrm{D}^{\mathrm{a}} \mathrm{M}^{\mathrm{a}} \mathrm{J}$. Jiménez Cisneros, en la zona de La Puntilla del Salado, en el término municipal de Rota, parecen formar parte de un contex to formado además por fragmentos de ánforas, presumiblemente de época romana, así como monedas, agujas y otros instrumentos de pesca. Estos datos nos indican la existencia en las proximidades de una factoría de salazones y una alfarería destinada a la elaboración de envases industriales para la comercialización de productos derivados de la pesca. 
Estos sellos, aunque presumiblemente de época romana, representan rosetas similares a las estampillas localizadas sobre ánforas púnicas del tipo TA1, fabricadas en los hornos de Torre Alta en San Fernando.

\subsection{Los materiales: estudio del material anfórico}

Dadas las características de una publicación como ésta, abordaremos ahora únicamente el estudio de las distintas formas anfóricas, dejando para las memorias correspondientes el estudio de los restantes tipos cerámicos.

Las ánforas constituyen un material arqueológico de primer orden para el estudio del comercio y las relaciones económicas entre los diversos pueblos del Mediterráneo en la Antigüedad. Los primeros ejemplares de estos envases llegaron a las costas andaluzas de manos de los fenicios, respondiendo en los primeros momentos (siglos VIII-VI a.C.) a unas cuantas formas, una de las cuales, la conocida como "ánfora de saco", alcanzó gran popularidad y desarrollo. Tanto es así que toda la producción anfórica posterior, por un lado la de los talleres de los centros fenicios occidentales y, por otro, la de los enclaves indígenas, deriva de este recipiente caracterizado por sus hombros carenados.

Estos envases evolucionaron a lo largo de los siglos, y lo hacen de forma lenta, consecuencia sin duda de su carácter utilitario, y no serán ajenos a diversas influencias y circunstancias históricas.

Las ánforas son por otro lado uno de los pocos testimonios que nos ha legado el pasado de aquel tráfico de mercancías (vino, aceite, conservas de pescado, etc.). La identificación del contenido de los envases fenicio-púnicos constituye, aún en nuestros días, una de las cuestiones más difíciles de resolver, problema en gran parte debido a la escasez de elementos epigráficos o de estampillas. De hecho son muy escasos los datos que poseemos en este sentido de los primeros momentos de la presencia fenicia en nuestras costas. No obstante las investigaciones más recientes, efectuadas en los últimos quince años, han deparado importantes datos que nos han permitido conocer algunos de estos aspectos, sobre todo para la producción posterior al siglo V a.C. Entre estos trabajos merece especial mención las notables investigaciones llevadas a cabo por nuestro colega J. Ramón en la isla de Ibiza, gracias a las cuales podemos hoy día disponer de una completa clasificación de ánforas elaboradas en los talleres púnico-ebusitanos, así como conocer las diversas importaciones llegadas a ese estratégico enclave fenicio-púnico (Ramon 1981a; Id. 1981; Id. 1985; Id.1991). En el área gaditana nuestras investigaciones acerca de los materiales anfóricos de la ciudad de Cádiz y sobre todo las excavaciones en factorías y alfarerías con la identificación del contenido de los envases gracias al hallazgo de un variado conjunto de marcas impresas, han posibilitado el avance de la investigación acerca de los orígenes y desarrollo comercial de una actividad industrial tan importante y preciada en la Antigüedad como era la elaboración de productos derivados de la pesca (Muñoz 1987; Id.1987a; Frutos, Chic, Berriatúa 1988: 295-306; Muñoz 1993: 328; Frutos, Muñoz 1994: 393-414).

El material anfórico procedente tanto de las factorías de salazones como de la alfarería de Torre Alta es muy fragmentario, por lo que en este artículo analizaremos únicamente las formas identificadas con total seguridad. Es de destacar que la totalidad de los fragmentos de la alfarería se ha podido adscribir a una de las seis formas definidas en ella. Un gran problema lo plantean una serie de bordes evolucionados de la forma arcaica Vuillemot R1 que aparecen en las factorías gaditanas y portuense y que normalmente se califican como producciones indígenas de tradición fenicia, ocupando una cronología que va desde el siglo VI a.C. al III a.C.. La fragmentación del material anfórico y la variedad de formas que enlazan con las producciones turdetanas e ibéricas, hacen hoy por hoy muy dificultosa su definición formal (Pellicer, Escacena, Bendala 1983; Florido 1984: 419-436; Muñoz 1987: 471 y ss).

Para una mejor comprensión y para evitar la multiplicidad de tipologías, utilizaremos la tabla tipológica que establecimos en 1987 para las ánforas prerromanas de Cádiz (Muñoz 1987: 471-478). Hemos definido un total de quince formas, correspondiendo ocho a producciones del área del Estrecho, de las cuales seis 
se fabricaron en los hornos de Torre Alta, cuatro a importaciones griegas, grecoitálicas o itálicas y tres a importaciones centro-mediterráneas.

\subsubsection{Producciones del área del Estrecho de Gibraltar}

\subsubsection{Forma A4a (fig. 12)}

Deriva de la forma fenicia arcaica y al igual que ella la encontramos ampliamente difundida por el Mediterráneo Occidental, llegando incluso algunos ejemplares a Grecia (Olimpia y Corinto) (Gauer 1975: 67; Williams 1979: plate 43).

Es a fines del siglo VI a.C. cuando se documentan los ejemplares más antiguos. De esta fecha es el fragmento de borde $n^{a} 1072$ del Cerro Macareno, calificable claramente en esta forma (Pelllicer, Escacena, Bendala 1983: 86, fig. 82) así como algunos de la factoría de la plaza de Asdrúbal, morfológicamente idénticos al anterior (Muñoz, Frutos, Berriatúa 1988: 489-490).También en estos primeros momentos podemos incluir algunos fragmentos de Kouass, incluidos en el tipo I de Ponsich (1969, Tipo I, fig. 1 nº I, abajo a la izquierda, los tres primeros bordes).

Esta forma alcanza su apogeo y mayor difusión en el siglo $\mathrm{V}$ a.C., iniciándose en el siglo IV a.C., probablemente desde su segunda mitad, una ligera evolución en la forma, que se ira plasmando en ciertos cambios, sin afectar al esquema general de la misma (cuello separado del sector superior del cuerpo por una carena -éste es estrecho y alargado, evolucionando de forma cónico-cóncavo a casi cilíndrico y sector inferior ojival-).

En las factorías de las Redes y en la de la Avda.. de Andalucía aparecen en el siglo V a.C. y buena parte del IV a.C. (Muñoz, Frutos, Berriatúa 1988: 487-508).

En cuanto al contenido de estos envases tenemos la suerte de contar con los datos arqueológicos suministrados por la excavación de C.H.K. Williams en Corinto, donde se documenta esta forma asociada a restos de pescado salado (Williams 1978: plate 43). Igualmente en la factoría de la Plaza de Asdrúbal, en las excavaciones de urgencia realizadas en 1985, se localizó en la denominada Zona $F$ un tercio inferior de esta forma conteniendo los restos troceados de un atún (Muñoz, Frutos, Berriatúa 1988: 489-490).

\subsubsection{Formas A4c-e (Torre Alta 1A) (fig. 12).}

Estas formas, contemporáneas y morfológicamente similares a la anterior, derivan de ella, diferenciándose sobre todo en el borde y en un alargamiento generalizado del cuerpo. En el caso de la A4c el sector superior del cuerpo está separado del inferior por una fuerte carena.

En las factorías gaditanas y portuense se fechan desde la mitad del siglo IV a.C. y durante todo el siglo siguiente (Muñoz 1987: 474; Id. 1993: 216-217; Muñoz, Frutos, Berriatúa 1988: 500; Frutos, Chic, Berriatúa 1988: 295-306).

Esta forma se fabricó en Torre Alta, donde representa un 32,8\% del total de fragmentos anfóricos (Frutos, Muñoz 1994: 398-400). Igualmente está documentada su producción en la ciudad de Cádiz en la alfarería de la c/ Tolosa Latour.

\subsubsection{Forma A4f (Torre Alta 1B) (fig. 12).}

$\mathrm{Al}$ igual que la anterior, deriva de la $\mathrm{A} 4 \mathrm{a}$, representando el último ejemplo en la evolución de aquélla.

En las factorías de la ciudad de Cádiz aparece sobre todo en el último tercio del siglo III a.C., continuando en vigor en los primeros años del siglo siguiente. En las Redes se fecha sobre todo en la segunda mitad del mismo siglo, incluso algo antes (Frutos, Chic, Berriatúa 1988: 295-306). 
En la alfarería de Torre Alta representa un 8\% del total de fragmentos anfóricos (Frutos, Muñoz 1994: 400). De la misma forma, está documentada en el vertedero de la C/Tolosa Latour de Cádiz.

\subsubsection{Forma A5 (Torre Alta 2) (fig. 12)}

Esta forma, según el estado actual de la investigación, se concentra en dos áreas, una circunscrita a Andalucía Occidental, con un foco de producción en el área de Cádiz, elaborándose en la alfarería de Torre Alta (Frutos, Muñoz 1994: 400-401), en un gran porcentaje (31,7\% del total de fragmentos anfóricos), y otro en el levante peninsular, donde se documentan tipos similares entre los siglos IV y II a.C. (Ribera 1982: 36).

En las factorías gaditanas aparece durante el siglo III a.C. (Muñoz 1987: 474-475). En las Redes se documentan en casi todos los momentos de su actividad, representando el segundo tipo más numeroso (Frutos, Chic, Berriatúa 1988: 295-306).

\subsubsection{Forma E1 (fig. 12)}

Es una forma con amplia difusión en Andalucía Occidental. La forma completa se documenta en el Cerro Naranja (Jerez de la Frontera, Cádiz), donde se fecha en la segunda mitad del siglo IV a.C. (González 1987: 93-94). La misma cronología ofrecen los materiales del Castillo de Doña Blanca (Ruiz 1986: Abb. 13). En contexto de factorías de salazones la encontramos en la Plaza de Asdrúbal, donde se fecha en los siglos IV y III a.C. al igual que en Las Redes (Frutos, Chic, Berriatúa 1988: 295-306). En el Cerro Macareno aparecen en los niveles 13 y 11 de la excavación de M. Pellicer, fechadas a principios y en el tercer cuarto del siglo IV a.C. (Pellicer, Escacena, Bendala 1983: 88, fig. 87: 1412, 1501, 2373).

En líneas generales, la forma E1 aparece en los comienzos del siglo III a.C., perdurando, en función de la información arqueológica conocida, durante todo el siglo siguiente, no existiendo constancia fidedigna de su presencia en siglos posteriores.

\subsubsection{Forma E2 (Torre Alta 3) (fig. 12)}

Es la forma más representativa de los hornos de Torre Alta, perteneciendo a esta forma un $35,5 \%$ del total de fragmentos anfóricos (Frutos, Muñoz 1994: 401-402). La forma completa la conocemos, entre otros yacimientos, en los distintos pecios de La Caleta, Cádiz (Muñoz 1993: 301-306). En las factorías gaditanas y portuense se documenta sobre todo en el siglo III a.C., especialmente en su último tercio. De la Plaza de Asdrúbal conocemos además un fragmento con una marca consistente en una cartela circular con representación de una pareja de atunes (Muñoz 1993: 302).

Esta forma estuvo en vigor durante todo el siglo II a.C., desapareciendo en los inicios del siglo I a.C. Su origen cronológico parece no situarse más allá del siglo III a.C., incluso sus características morfológicas, inspiradas quizás en producciones centro-mediterráneas que no llegan a nuestras costas hasta el último tercio del siglo III a.C., nos hacen pensar en el inicio de su producción en estas fechas. En este sentido, la cronología atribuida a los fragmentos del Cabezo de San Pedro (Huelva), del siglo IV a.C., nos parece demasiado alta (del Amo, Belén 1981: 99, 137, fig. 18 nº 31).

\subsubsection{Forma F1 (Torre Alta 4) (fig. 12).}

Esta forma constituye la variante occidental del ánfora cartaginesa conocida como Mañá C2. Su dispersión, como apunta J. Ramón, es muy similar a la de las fenicias arcaicas (Vuillemot R1), es decir, las costas andaluzas, Levante Peninsular, Baleares, Cataluña y las costas francesas, actuando en este comercio la isla de Ibiza como receptora y emisora de estos envases hacia el norte (Ramon 1981a: 42).

En el área de producción gaditana encontramos esta forma en Torre Alta, alcanzando únicamente el 0,3\% del total de fragmentos anfóricos (Frutos, Muñoz 1994: 402). 
En la zona africana podemos citar como yacimiento clave los talleres de Kouass, con cronología del siglo II a.C. (Ponsich 1969: 85, fig. 2, IV).

Cronológicamente y según los datos arqueológicos de contextos definidos, esta forma aparece desde la segunda mitad del siglo II a.C. hasta aproximadamente el tercer cuarto del siglo I a.C. (Muñoz, Frutos, Berriatúa 1988: 500; Arteaga 1985: 213-219, fig. 4-8).

\subsubsection{Forma Torre Alta 5 (fig. 13).}

Esta forma está solamente documentada en la alfarería de Torre Alta, conociendo únicamente unos cuantos fragmentos de bordes de sección triangular y un fragmento de cuello, asa y espalda. La forma de ésta última, al ser curvilínea sin arista de unión entre el hombro y el cuerpo, se distancia de los esquemas tradicionales del ánfora grecoitálica. Su forma recuerda a las denominadas ánforas "G" del Sec, de gran parecido morfológico al tipo IX de la nave de Kyrenia (Frutos, Muñoz 1994: 403; Wylde, Katzev 1973: 339-355), o a la denominada Will C (Lamboglia 4, grecoitálica-tardía) (Manacorda 1986: 581-586)

\subsubsection{Importaciones griegas, grecoitálicas e itálicas}

\subsubsection{1. Ánforas Corintias A' (fig. 13)}

Esta forma está documentada únicamente en la factoría de la Plaza de Asdrúbal. Desde el punto de vista cronológico se data desde el segundo cuarto del siglo $\mathrm{V}$ a.C. hasta la mitad del siglo siguiente (Koehler 1981: 449-458; Id. 1978a: 321-339; Id. 1978b,). Se diferencia de las demás corintias principalmente en el borde que presenta sección triangular con su cara externa aristada.

Además de en la ciudad donde se fabricaron, las encontramos en Pithecousa (di Sandro 1986) y en diversos yacimientos de Lipari (Cavalier 1985).

\subsubsection{2. Ánforas Corintias B (fig. 13)}

Tienen sus orígenes en el último cuarto del siglo VI a.C., presentando una evolución desde cuerpos ovoides y bordes redondeados a bordes de tendencia triangular invertida. Estos últimos tienen sus paralelos más directos en los materiales del Agora de Corinto, en donde aparecen asociados a una forma característica del área gaditana como es la Mañá-Pascual A4, fechada allí a partir del 480 a.C. (Williams 1979: 105-144).

Esta forma aparece en las factorías gaditanas de la Plaza de Asdrúbal y de la Avda. Andalucía y en la portuense de Las Redes.

\subsubsection{3. Ánforas grecoitálicas e itálicas (fig. 13)}

En líneas generales las primeras responden al tipo 4 de Lamboglia, I de Benoit, teniendo una difusión muy amplia y ocupando en nuestros yacimientos los siglos III y II a.C.

Por lo que se refiere a las itálicas, responden a la forma Dressel 1, fechándose en los siglos II y I a.C.

\subsubsection{Importaciones centro-mediterráneas}

\subsubsection{1. Ánforas Merlín-Drappier 3 (fig. 13)}

Estas ánforas tienen sus centros originarios en los enclaves púnicos del Mediterráneo Central, en Cartago y Sicilia. Su cronología general se sitúa durante el siglo III a.C. En la Península podemos citar, siguiendo a J. Ramón, los ejemplos del pecio Cabrera 2, una pieza aislada del litoral de Ibiza, la Neápolis de Ampurias, el ejemplar completo de Doña Blanca y los fragmentos de la factoría de Las Redes (Ramon 1986-89: 230-232). 


\subsubsection{2. Ánforas Mañá D (fig. 13)}

Su origen centro-mediterráneo parece hoy día incuestionable.

Los tipos de esta serie, las variantes 1a, lb y 2 de Solier, parecen llegar a la Península en época de los Bárcidas, en el último tercio del siglo III a.C. Los materiales de las factorías gaditanas y de El Puerto de Santa María apoyan esta cronología, no documentándose en momentos anteriores (Ramon 1995: 96, 559, fig. 196).

\section{CONSIDERACIONES EN TORNO A LA OBTENCIÓN DE LA MATERIA PRIMA, SU ELABORACIÓN Y SU COMERCIALIZACIÓN}

Los recientes hallazgos de la ciudad de Cádiz, en concreto en el solar del antiguo Teatro Andalucía (ver 2.1.6), nos hacen remontar a finales del s. VII a. C. el uso de las salazones como producto alimenticio. El panorama arqueológico de estos restos es prácticamente idéntico al que Jodin encontró hace ya más de treinta años en el islote de Mogador, con los mismos tipos anfóricos -el correspondiente a las formas T10.1.2.1 de J. Ramón ${ }^{55}$ - y con las mismas huellas de fogatas en los alrededores, con abundantes restos de malacofauna y de huesos y espinas de pescados. Estos descubrimientos vienen a complementar otros vestigios relacionados con la actividad pesquera en diversos puntos de las costas del sur de la Península Ibérica y del norte de África: en el Cabezo de San Pedro (Huelva) se han encontrado restos de atún de tamaño considerable en estratos correspondientes a la segunda mitad del s. VII a. C. (Comunicación verbal de D. José Ortega Blanco); de cronologías similares con prolongación al primer tercio del s. VI a. C. son los hallazgos de Rachgoun y Mersa Madakh (Aubet 1994: $251 \mathrm{ss);} \mathrm{o} \mathrm{los} \mathrm{del} \mathrm{litoral} \mathrm{malagueño} \mathrm{en} \mathrm{Toscanos} \mathrm{y} \mathrm{el} \mathrm{Cerro}$ del Villar (Niemeyer 1982: 117; Aubet 1990). En fin, este cuadro se puede ampliar hacía las costas Atlánticas portuguesas, de las que la factoría fenicia de Abul, en la desembocadura del río Sado, es el exponente más significativo, con un elenco material muy similar al de Mogador y al del entorno general correspondiente al llamado Círculo del Estrecho (Mayet, Tavares 1992: 315-333; Chic 1994: $56 \mathrm{ss).}$

Todo esto corrobora la vocación marinera y la antigüedad de estas producciones gaditanas, que anuncia o augura su fama y prosperidad posterior, cuando adquieran carácter industrial y se conviertan en alternativa económica de exportación, compensando a la de otros productos como la plata o el estaño en franca regresión en cuanto a su cotización en los circuitos comerciales internacionales. Este fenómeno que, como veremos, sucede hacia finales del siglo VI a. C. viene precedido por una época -la que estamos tratando- en la que las producciones derivadas de la pesca parecen estar dedicadas al autoabastecimiento de los colonos o, a lo sumo, ser mercancía de intercambio de segundo orden: lo creemos así por el hecho de que los vestigios conserveros más antiguos se hallan contenidos en recipientes estándar, los antes descritos (las ánforas llamadas también R-1 evolucionadas), que estaban destinados a contener otros productos diversos (cereales, aceite, vino, etc.) y, por consiguiente, no eran específicos de estas conservas como luego ocurrirá (Aubet 1994: 48 ss; Gsell 1972: 312; Arteaga 1994: 27 ss). Por otra parte, tenemos también que el emporio de Mogador, que tanta prosperidad comercial documenta a través de los múltiples y variados hallazgos de diverso abolengo, sufre un abandono prolongado que se extiende desde el segundo cuarto del siglo VI a. C. hasta fines del III a. C., precisamente en los momentos en los que se desarrolla la época de mayor esplendor de la industria pesquera. Por lo demás, la ausencia de estructuras arquitectónicas es otro punto a tener en cuenta para considerar la idea de que Mogador era punto de encuentro comercial de carácter temporal, donde quizá se llevara a cabo el "intercambio silencioso" entre los indígenas de la costa de enfrente y los comerciantes semitas, tal y como nos relata el considerado "Padre de la Historia" por Cicerón (Hdt. IV, 196; Frutos 1994: 195-200). No es, por tanto, probable, a tenor de estas consideraciones, que este enclave estuviera dedicado a la actividad pesquera y menos aún a la producción de conservas derivadas de ella, como se ha venido sosteniendo con cierta asiduidad por algunos estudiosos (López 1993: 354; García y Bellido 1985: 220 ss). 
De acuerdo con todo lo expuesto anteriormente la modalidad del ejercicio de la pesca versaría fundamentalmente en el uso de redes móviles y del anzuelo en sus diversas variantes (Aubet 1990). Las frecuentaciones de las aguas del Atlántico y del Mediterráneo por el gran trasiego comercial que se desarrollaba por estas fechas, llevarían a los fenicios al descubrimiento del fenómeno de los ciclos migratorios anuales de los escómbridos (atunes, caballas, bonitos, toninos, etc.) que, desde los meses de mayo y junio desarrollan desde las aguas frías del Océano a las templadas del Mare Nostrum, pasando por el estrecho, con el fin de llevar a cabo el desove para la reproducción. A partir de finales de junio y durante el mes de julio se produce el retorno, siguiendo las mismas rutas a la inversa, a los lugares de origen (Plin. IX, 18-19; Ponsich, Tarradell 1965: $97 \mathrm{ss}$ ). Este episodio coincide precisamente con la época del año considerada más idónea para llevar a cabo el ejercicio de la navegación de forma más segura (Chic 1994: 56 ss).

El siglo siguiente es una etapa oscura, muy difícil de definir en sus justos términos debido a las grandes carencias de documentos literarios y arqueológicos (y quizá también a una serie de deficiencias en los métodos de análisis y de interpretación, como sugiere algún autor) (Arteaga1994: 40 ss). Lo que sí parece cierto es que se produce una importante crisis del sistema productivo y de su entramado social y político, originado por el colapso del comercio de la plata, a lo que hay que añadir posiblemente una serie de acontecimientos políticos coincidentes en todo el ámbito mediterráneo (Chic, Frutos 1984: 209 ss; Frutos 1991: 71 ss). En el panorama colonial occidental se rompe el entramado de su dinámica de relaciones de interdepencia políticoeconómica entre ellas y para con la metrópolis, produciéndose una atomización que tendrá como resultado una reestructuración de su sistema de organización socio-económico interno, en lo que algunos autores han definido como emergencia o transformación en poleis (Arteaga 1994:42 ss). En el plano de los contactos con los colonizados se produce un cambio radical, puesto que esas relaciones previamente acordadas mediante posibles pactos de mutuo acuerdo teniendo como base el intercambio en base a la plata, acaban rompiéndose, teniendo como consecuencia una etapa de inestabilidad que desembocará, por un lado, en la descomposición del sistema político tartésico y de su identidad cultural, y por otro, en una situación de enfrentamientos bélicos entre indígenas y colonizadores, quizá también debido esto último a las nuevas orientaciones económicas derivadas de la reconversión necesaria para superar la crisis (Macr.Sat, I, 20, 12; Just. XLIV, 5, 1-3). Esta reconversión consistiría en una concentración de la población colonial reforzando determinados enclaves de antigua fundación (Gadir, Ebusus, Malaca, Abdera, etc.) o bien erigiendo otros nuevos (Villaricos), generando, a la par, el abandono de otros lugares (Toscanos, Alarcón, Cerro del Prado, Rachgoun, etc.). El reagrupamiento del contingente colonial -unido a los elementos de nueva incorporación procedentes de Oriente y del norte de África-implicaría una necesidad de expansión territorial, con el fin de ampliar la chora productiva de cada una de estas poleis: puesto que las nuevas tendencias económicas se centrarán ahora en un sistema productivo basado en la creación de importantes excedentes de los recursos mineros, agropecuarios, pesqueros y sus derivados industriales (metales, vino, aceite, salazones y salsas). En todo este nuevo horizonte, que hemos diseñado en breves rasgos, Cartago debió tener un papel destacado, puesto que es la ciudad norteafricana la que ayuda de manera decisiva a la ciudad de Gadir en los antedichos enfrentamientos con los indígenas, o la que abre la política de anexión territorial por el interior peninsular meridional (Frutos 1991: 71 ss; López 1991: 73 ss), o, en fin, la que reorganiza las navegaciones por el Atlántico con el objetivo de crear nuevos emporios o de abrir nuevos mercados (periplos de Hannon e Himilcón). A partir de aquí se produce una nueva situación de relaciones entre ciudades que algunos autores han definido como liga, con Gadir a la cabeza, mecanismo que emula al que desde tiempos anteriores se había conformado en el Egeo (Arteaga 1994: 41 ss). En el plano de las relaciones exteriores se desarrolla una política de contacto entre las diferentes ligas basados en acuerdos internacionales donde se concretan los aspectos económicos y políticos y se clarifican las respectivas esferas de influencia de los firmantes.

En todo este contexto de transformaciones, la pesca y sus derivados se van a erigir en una actividad económica que va a generar importantes riquezas entre las distintas ciudades del sur de la Península, en especial 
en Gadir. El momento emergente parece iniciarse, a tenor de los hallazgos arqueológicos, en las postrimerías del siglo VI a. C, con la aparición de los primeros centros especializados de producción en torno al estrecho (Aljaraque, Puerto de Santa María, Cádiz) y la aparición de los primeros recipientes destinados exclusivamente a su envasado (ánforas Mañá-Pascual A4 iniciales, ver fig. 2). Podemos observar desde estos momentos un proceso de cambio que se define por el paso de una producción de carácter artesanal a una de claro nivel industrial, encaminada a obtener gran cantidad de excedentes con vistas a satisfacer una demanda cada vez más numerosa, dado que estos productos gaditanos estaban ya a principios del $\mathrm{s}$. V a. C. ampliamente difundidos $\mathrm{y}$, por consiguiente, consolidados totalmente el mecanismo de su comercialización.

Todo esto debió traer consigo unas nuevas formas de obtención de la materia prima, orientadas a una explotación más intensiva de los recursos marinos necesarios para la fabricación masiva de estos productos; se ingenian nuevos métodos de pesca: la almadraba y los corrales, que se unen a los utilizados en épocas precedentes. De las primeras tenemos testimonios escritos de su uso en época romana (Opp. H. III, 597 , 641), y se utilizaban, tal como en la actualidad, para la pesca del atún. Consiste fundamentalmente en una red extendida y dispuesta en forma circular, anclada en el fondo del mar por su extremo inferior y sostenida por boyas o flotadores por el superior. A lo largo de su extensión tiene una serie de aberturas por donde penetran los atunes, a los que una vez en su interior les resulta casi imposible salir, tendiendo a subir a la superficie, en la que los pescadores les esperan para capturarlos con unos garfios especiales (Moreno, Abad 1971: 213). Este sistema de pesca era utilizado en el período de tiempo correspondiente a los ciclos migratorios de los atunes (Plin. H. N. IX, 18-19; Opp. H. III, 643, 644). El carácter estacional que tiene la pesca del atún ha llevado a algunos autores a considerar la posibilidad de que la industria de salazones y salsas tuviera también un corto período de funcionamiento, ceñido a la época estival, que es cuando se efectúa el paso de los bancos de los escómbridos por aguas del estrecho (Belén, Fdez-Miranda 1978: $197 \mathrm{ss;} \mathrm{Ponsich} \mathrm{1975:}$ 676; López 1993: 358). Sin embargo la segunda modalidad de captura del pescado, los corrales, nos hace discrepar de tal criterio interpretativo. Los corrales son depósitos que se construían en la línea costera, a fin de tener asegurada la provisión de peces sin tener que aventurarse en el mar para ello. Estas construcciones se realizaban aprovechando y acondicionando los escollos y los bajos fondos; a veces eran totalmente artificiales, construidos a base de sillares y/o de madera. Su mecanismo de funcionamiento dependía del ciclo de las mareas: así, con la pleamar, los peces se introducirían en los corrales, mientras que con la bajamar las aguas se irían retirando lentamente a través de las hendiduras de las paredes, quedando los peces atrapados en el interior (Moreno, Abad 1971:214 ss). Diferentes indicios apoyarían la existencia desde época antigua de estos viveros: el testimonio de Plinio (H.N. IX. 19; Trad. G. Chic), los hallazgos de dichas estructuras en exploraciones submarinas entre la desembocadura del río Barbate y el Estuario del Cachón (Moreno, Abad 1971: 214 ss), así como una serie de topónimos que recuerdan su existencia: Corrales, localidad de la provincia de Huelva a muy corta distancia de Aljaraque; Playa de Los Corrales, en Cádiz, etc..

La existencia de estos depósitos no sólo aseguraría una provisión continua de materia prima para las factorías, sino que también conllevaría la utilización de una mayor variedad en cuanto a tipos de peces se refiere para la elaboración de estos productos industriales, teniendo como consecuencia por un lado, una gran variedad de salazones y salsas (Plin. H.N. XXXI, 31,43-44; Gp. XX, 46, 1; Garg. Mart. 62)y, por otro, que las fábricas estuvieran funcionando de manera ininterrumpida durante todo el año. Explicaría también su gran difusión por, prácticamente, todos los centros urbanos y rurales del Mediterráneo y del Atlántico, sugiriendo que estos diversos tipos de productos estaban al alcance de todos los bolsillos y gustos. La multiplicidad de estos productos no solamente dependía de los recursos marinos empleados, sino también de su mezcla con otros ingredientes alimenticios, así como de los diferentes tipos de condimentos con los que se combinaban, buscándose con ellos tanto una finalidad nutritiva como terapéutica (Curtis 1991: 6 y ss).

La constatación arqueológica indica que formaban parte de la dieta alimenticia de los contingentes militares, como lo viene a demostrar el importante impulso que adquiere su fabricación durante la segunda guerra 
púnica, de lo que son buenos botones de muestra el complejo de Torre Alta y la dispersión de los tipos anfóricos correspondientes por el interior andaluz, levantino y norteafricano, siguiendo la ruta de los acontecimientos. Otra confirmación en este mismo sentido la constituyen los hallazgos de ánforas tipo E-2 en los campamentos de las tropas romanas que asediaban la ciudad de Numancia poco antes de su caída, acaecida en el año 134 a.C (Sanmartí 1985: 133 ss; Ferrer, García, e. p.).

Como cabe suponer, en base a las referencias de los escritores antiguos, las salazones y salsas derivadas del atún eran las más apreciadas. En los mercados internacionales alcanzaban precios elevadísimos: así, en el s. IV a. C. se proponían éstas como uno de los grandes placeres al que cualquier amante del buen comer y de la buena vida -con medios económicos suficientes para procurársela, por supuesto-podía aspirar (Nic., Com, ed. T. Kock, C.A.F.). Plinio nos dice que por dos congios (unos 6,5 1.) de garum sociorum se pagaban 1000 sestercios, advirtiendo que "casi ningún otro producto líquido, a excepción de los perfumes, ha alcanzado un precio más elevado, dando fama también a las gentes que lo producen" (Plin. H.N., XXXI, 43). Como hemos puesto de relieve anteriormente, el precio de estos productos aumentaría aún más en función de otras variables como las mezclas con otros alimentos y condimentos que se le añadían: vino, aceite, miel, vinagre, etc.(D'Aremberg, Saglio), o bien con determinados aderezos a base de verduras o hierbas aromáticomedicinales: cilantro, hinojo, apio, ajedrea, orégano, ruda, poleo, adormidera, semillas de alhova, pimienta, canela, clavo, etc. (Garg. Mart., 62; Casson 1980: 21 ss). No nos extrañaría en este sentido, que las denominadas "cerámicas de importación", que suelen aparecer entre los materiales proporcionados por estas factorías, fueran los recipientes que contuvieran algunas de estas citadas materias alimenticias, como hemos puesto de relieve en otro trabajo anterior (Frutos, Chic, Berriatúa 1988: $301 \mathrm{ss).} \mathrm{Tampoco} \mathrm{hay} \mathrm{que}$ descartar, por último, que también influyera en el precio la modalidad elegida para su elaboración, en el sentido de si se empleaba el método tradicional o el sistema de fabricación acelerado. En el primero el preparado no se obtenía hasta pasados dos meses, en un proceso que va desde la obtención del punto de la salmuera (muria) hasta su fermentación o autodiálisis por exposición al sol (Col. r.r. XII,6; Gp XX, 46,1; Garg. Mart. 62). Con la segunda opción, la fabricación se aceleraba considerablemente, puesto que en vez de aguardar a la lenta cocción mediante los efectos del sol se empleaba la acción directa del fuego, bajo la forma de elevarlo a hervor hasta obtener resultados similares al anterior $(G p . \mathrm{XX}, 46,1)$.

Los hallazgos arqueológicos iniciales de estos centros de producción nos llevó a sostener la idea, a igual que otros investigadores, de que eran pequeñas unidades productivas de régimen familiar (Ruiz 1986: 243; López 1993: 358). Sin embargo, descubrimientos posteriores, como el complejo de Torre Alta, nos induce a un replanteamiento de esta interpretación: puesto que en este yacimiento se han detectado en una primera fase de investigación un importante centro de fabricación de envases exclusivamente dedicados a contener los productos derivados de la pesca. Recientes excavaciones han sacado a la luz, además de nuevos hornos, varias escombreras que contenían un importante cúmulo de restos de moluscos, conchas de cefalópodos, espinas y huesos de pescados, junto a restos cerámicos de desecho (fallos de cocción) y numismáticos, entre otros. El análisis de estos restos, además de otros de similares características encontrados en diversos lugares de la ciudad de Cádiz, nos lleva a la conclusión de que las factorías de salazones formaban parte de un conjunto mucho más amplio en el que además de estas células productivas lo conformarían los mencionados alfares y un grupo de dependencias destinadas a almacenaje de todos los elementos necesarios para el proceso de fabricación y de las actividades industriales auxiliares asoçiadas a ella (madera, sal, aljibes, etc.). Completaría la unidad de producción las oficinas donde se llevarían a cabo el control de gestión y contabilidad de la producción, como hemos puesto de relieve en otro trabajo (Chic 1994: 186; Frutos, Muñoz 1994: 403 ss).

Para terminar nuestras conclusiones, nos centraremos ahora, aunque sea brevemente, en algunas reflexiones en torno a proceso de comercialización de estos productos. Para nuestro ensayo de interpretación nos ha sido de capital importancia, una vez más, los hallazgos de Torre Alta, en concreto un grupo de marcas de ánforas con distintos motivos iconográficos: representaciones de Tanit, las que tienen como tema lo que 
hemos denominado roseta de ocho pétalos y, en fin, otras que dibujan los contornos de figuras humanas portando peces (quizá atunes) o desarrollando la elaboración de envasado de productos en recipientes de nuestra forma 3, y que en otro lugar calificamos como cadus, un ánfora que a nuestro parecer debió de estar

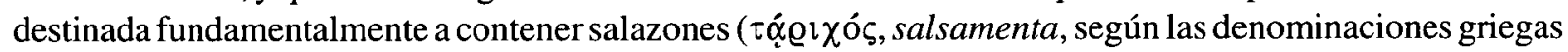
y romanas, respectivamente) (Frutos, Chic, Berriatúa 1988: $300 \mathrm{ss}$ ).

Creemos, y ya lo hemos puesto de relieve en otro lugar (Frutos, Muñoz 1994: 404 ss), que estas marcas testimonian que esta actividad industrial y su comercialización estaban bajo control del Estado o, si se quiere, ciudad-estado. En este sentido, hemos de tener presente que el sellado de las vasijas se efectúa in situ en los complejos industriales, puesto que se lleva a cabo cuando la arcilla está blanda, es decir, antes de cocerla. De acuerdo con esto, la administración controlaba a través de un proceso de contabilidad en la fabricación de los recipientes la dinámica productiva de las salazones y salsas, en definitiva, de todo el proceso económico. La marca, por tanto, era un procedimiento administrativo estatal que tendría como objetivo evitar el hurto de los productos durante su almacenaje, garantizar, a la vez, que su comercio se realizara por los "cauces legales" trazados a través de los acuerdos internacionales entre Estados, amén de certificar también el contenido de las ánforas en dicho proceso (Seyrig 1970: $227 \mathrm{ss)..}$

El hecho de utilizarse emblemas de Estado (signo de Tanit, roseta) habla ya de unas relaciones económicas interestatales, y por consiguiente de un proceso comercial pactado previamente, lo que algunos autores definen como comercio administrativo (Polanyi 1978: 307 ss; González 1984: 211 ss; Arteaga 1994: 43 ss). En este caso las divinidades son las garantes principales de que dichos pactos se lleven a su cumplimiento, tal y como en el caso posterior de los tratados que Aníbal suscribió con Filipo V de Macedonia en el 215 a. C. (Pol. VII, 9). De cómo se desarrollaba la dinámica y el ejercicio de estos acuerdos nos lo ponen de relieve los testimonios de Polibio en torno a los concertados entre Roma y Cartago, con sus respectivos aliados (Pol. III, 22-24). Según estas noticias, los aspectos económicos contenidos en estos acuerdos se enmarcaban legalmente mediante la certificación de funcionarios dependientes de los gobiernos en el lugar donde se efectuaban los intercambios, que en el caso de estos tratados eran Cartago, la parte de Sicilia controlada por los cartagineses (Motia, Solunte, Panormo), o en Roma y sus ciudades aliadas (Masilia, Emporio). De acuerdo con esto, estamos posiblemente ante un caso demostrativo de una institución característica de las formas administrativas de comercio en el mundo antiguo, cual es el puerto de comercio, entendiéndolo como el lugar donde se desarrolla el comercio institucional (Frutos, Muñoz 1994). Con este procedimiento se controlaba por parte de las ciudades firmantes no sólo las exportaciones sino también las importaciones y la dinámica de su distribución, lo que, a su vez, -de acuerdo con C. R. Whittaker-es un elemento más de control político (Whittaker 1978: $80 \mathrm{ss}$ ). A tenor de nuestra interpretación, no nos extraña en absoluto que algún investigador que defiende un modelo de producción y comercialización de las salsas y salazones basado en la iniciativa de pequeños propietarios y comerciantes no le encuentre explicación satisfactoria a la información que nos proporciona el comediógrafo ático, de hacia el 380 a. C., sobre la introducción furtiva de garum gaditano en Atenas, hecho que sí tendría sentido desde la perspectiva de nuestros planteamientos (Nicostr. Com. Ed. T. Kock, C.A.F., II, 219; Meigss, Lewis 1971 nº 93; Chic, Frutos 1984: 217 ss). Como también dejaría de parecernos una exageración la declaración formal de guerra entre cartagineses y foceos de Masilia por la captura de unas naves de pesca (Just. XLIII, 5, 2; Paus. X, 8, 7).

En lo descrito hasta ahora hemos resaltado a través de los testimonios escritos la participación de Cartago en todo este entramado resultante de la relación que hemos diseñado en base a los acuerdos internacionales. Pero hay otras informaciones de escritores antiguos que van en la misma dirección y más específicamente en lo que atañe a la aplicación directa al comercio de las salazones gaditanas. En este sentido, es de capital importancia la noticia que nos ha transmitido el llamado Pseudo Aristóteles: "dicen que los fenicios que habitan como colonos que se llama Gadir, navegando fuera de las columnas de Heracles con viento del este durante cuatro días, llegaron de improviso a unos lugares desiertos, llenos de junco y alga, que cuando 
había marea baja no estaban sumergidos, [y] cuando había marea alta estaban cubiertos de agua, en los cuales se encontraban una multitud exagerada de atunes e increíble por los grandes tamaños y grosores, siempre que llegan a la costa; salándolos y metiéndolos en vasijas los transportan a Cartago. De éstos sólo los cartagineses no hacen exportación en su provecho, sino que por la calidad que tienen como alimento lo consumen ellos mismos" (Ps. Arist. Mir., 136). Según esta noticia los gaditanos son los que se encargan de la pesca y de la elaboración, transformación y envasado de la materia prima. También son los que deben efectuar la labor del transporte de las mercancías hacia Cartago, puerto de comercio de carácter internacional, donde se procedía al intercambio con los Estados firmantes de los acuerdos bajo garantía administrativa mediante certificación de las operaciones a través de funcionarios encargados de dicho cometido. Este control cartaginés vendría también apoyado por las marcas en ánforas con la representación de Tanit, que hemos encontrado en Torre Alta. Entendemos que este fenómeno estaría en vigor hasta finales del siglo III a.C. momento en que empieza a proliferar el motivo de la roseta de ocho pétalos, hasta acabar por imponerse totalmente al anterior de Tanit en un momento que podríamos hacer coincidir con la destrucción de Cartago, en torno al 146 a. C.

El motivo de la roseta es un emblema iconográfico que representa a Gadir y su zona de influencia (la Liga púnico-gaditana), tanto a nivel político como económico y cultural. Se detecta también en la orfebrería gaditana desde, al menos, el siglo VI a. C.. También forma parte de la llamada -creemos que con poco aciertocerámica de kuass, coincidiendo su presencia con el auge de la industria salazonera. Un reciente estudio sobre elementos numismáticos, en su acepción religiosa, define un símbolo parecido a la roseta (la estrella) e idéntico al cuño encontrado en Rota, como representación solar asimilable a Melqart, en su vertiente de dios protector de la navegación (Chaves, Marín 1992: 181 ss). Pues bien, estos elementos empiezan a definir no sólo la independencia comercial de Gadir en el momento anteriormente descrito sino también demostraría un significado de garantía de origen de las mercancías además de certificar la calidad del producto. Los mismos conceptos que tendrán las marcas correspondientes a las mencionadas figuras humanas en sus actividades ya descritas, o algunas otras que imprimen los dos atunes, aunque la diferencia en las representaciones de las marcas estribaría quizá en que éstas últimas serían específicas para los productos de salazón, puesto que sólo se imprimen en nuestra forma 3 o en algún caso atípico (forma 5), la que hemos definido como cadus destinadas posiblemente a contener esta variedad de productos como hemos señalado anteriormente.

\section{BIBLIOGRAFÍA}

AMO del, M., BELÉN, M. (1981): "Excavaciones en el Cabezo de San Pedro". Huelva Arqueológica VI.

ARTEAGA, O. (1985): "Excavaciones arqueológicas en el Cerro del Mar (Campaña de 1982). Una aportación preliminar al estudio estratigráfico de las ánforas púnicas y romanas del yacimiento". Not. Arq. Hisp. 23. Madrid.

- (1994): "La liga púnica gaditana. Aproximación a una visión histórica occidental, para su contrastación con el desarrollo de la hegemonía cartaginesa, en el mundo mediterráneo", VIII Jornadas de Arqueología fenicio-púnica. Ibiza.

AUBET, M".E. (1990): "Cerro del Villar, Guadalhorce (Málaga). Campaña de excavaciones de 1989". III Jornadas de Arqueología Andaluza. Cádiz.

- (1994): Tiro y las colonias fenicias de occidente. Barcelona.

BELÉN, M., FERNÁNDEZ-MIRANDA, M. (1978): “La Tiñosa (Lepe, Huelva)". Huelva Arqueológica, IV. BLANCO, F.J. (1991): "Excavaciones de urgencia en un solar de la calle Doctor Gregorio Marañón. Cádiz". $A A A^{\prime}$ '89. Sevilla.

CASSON, L. (1980): “Rome's trade with the East: The sea voyage to Africa and India". T.A.P.A., I10. 
CAVALIER, M. (1985): "Les amphores du VIo au IVํò̀cle dans les fouilles de Lipari”. Cahiers des amphores archaïques et classiques. 1.

CURTIS, I.A., (1991): Garum and salsamenta. Production and Commerce in materia medica. Leiden.

CHAVES, F., MARÍN, Mª.C.,(1992): "L'influence phénico-punique sur l'iconographie des frappes locales de la Penínsule Ibérique".Studia Phoenicia IX.

CHIC, G., (1994): "Roma y el mar: del Mediterráneo al Atlántico". Del Mundo Antiguo a la Edad Moderna. Ferrol.

CHIC, G., FRUTOS, G. de, (1984): "La Península Ibérica en el marco de las colonizaciones mediterráneas”. Habis 15.

DAREMBERG, CH., (1904): Dictionnarie des Antiquités Classiques. París.

FERRER, E., GARCÍA, E., (en prensa): "Sobre un tipo anfórico púnico- gaditano documentado en el Cerro de la Cruz (Almedinilla, Córdoba)".

FLORIDO, C., (1984): “Ánforas prerromanas sudibéricas.” Habis 15.

FRUTOS, G. de. (1987): Las relaciones entre el norte de África y el sur de Hispania desde la colonización fenicia a la decadencia de Cartago. Edición mocrofichada. Sevilla.

- (1991): Cartago y la política colonial. Los casos norte africano e hispano. Écija.

(1994): "Consideraciones entorno al emporio de Mogador", Homenaje a José Ma . Blázquez, vol. II. Madrid.

FRUTOS, G.de, CHIC, G., BERRIATÚA, N., (1988): "Las ánforas de la factoría prerromana de salazones de Las Redes (El Puerto de Santa María, Cádiz)”.'Actas del I Congr. Penins. de Historia Antigua. Santiago de Compostela.

FRUTOS, G. de, MUÑOZ, A., (1994): “Hornos púnicos de Torre Alta (San Fernando, Cádiz)”. Arqueología en el entorno del Bajo Guadiana. Huelva.

GARCÍA Y BELLIDO, A., (1985): La Península Ibérica en los comienzos de su Historia. Madrid.

GAUER, W. (1975): "Die tongesafässe aus den Brunnen unter Sadión-Nordwale und in Sudest-Gebiet" Olimpische Forschungen VIII.

GONZÁLEZ, R., (1987): “Cerro Naranja. Un asentamiento rural púnico en la campiña de Jerez”. $A A A$ '85. Sevilla.

GSELL, S., (1920-28): Histoire.Ancienne de l'Afrique du Nord. Vol II. Paris. (R. 1972).

KOEHLER, C.G., (1978): "Evidence around The Mediterránean for Corinthian Export of wine and oil". Beneath the waters of time: The proceding of The Ninth Conference on Underwater Archeology. Texas. (1978a): Corinthian A and B transport amphoras. Princenton University.

(1981): "Corinthian developments in the study of trade in the Fifth Century". Heperia 50.

LÓPEZ, J.L. (1991): "Cartago en la Península Ibérica: ¿imperialismo o hegemonía?". V Jornadas de Arqueología fenico -púnica. Ibiza.

_ (1993): "La producción fenica occidental de salazón de pescado". Il Congr. Peníns. De Hisisria Antigua. Coimbra.

MANACORDA, D., (1986): “ A proposito delle anfore cosidette greco-italiche. Una breve nota”. Recherches sur les amphores grecques. Bulletín de Correspondence Hellénique.

MAYET, F., TAVARES, C., (1992): "Abul: um estabecimento orientalizante do sec. VII a.C. no baixo vale do Sado". Setubal Arqueológica IX-X.

MORENO, A., ABAD, L. (1971): “Aportaciones al estudio de la pesca en la Antigüedad”. Habis 2. Sevilla. MUÑOZ, A. (1987): "Las ánforas prerromanas de Cádiz. (Informe preliminar)”. AAA'85. Sevilla.

— (1993): "Las cerámicas fenicio-púnicas de origen submarino del área de la Caleta (Cádiz)”. Cuadernos de prehistoria y arqueología castellonenses 15 . Castellón. 
MUÑOZ, A., FRUTOS, G. de, BERRIATÚA, N. (!988): “Contribución a los orígenes y difusión comercial de la industria pesquera y conservera gaditana a través de las recientes aportaciones de las factorías de salazones de la Bahía de Cádiz". Congr. Inter. El Estrecho de Gibraltar I. Ceuta 1987. Madrid.

NIEMEYER, H.G., (1982): "El yacimiento fenicio de Toscano: balance de la investigación 1964-1979". Huelva Arqueológica VI.

PELLICER, M, ESCACENA, J.L., BENDALA, M. (1983): “El Cerro Macareno".Exc. Arq. Esp. 124. PERDIGONES, L., MUÑOZ, A., (1990): "Excavaciones arqueológicas de urgencia en los hornos púnicos de Torre Alta, San Fernando, Cádiz". AAA' 88 . Sevilla.

PONSICH, M., TARADELL, M.(1965): Garumet industries de salaisón dans la Mediterránèe Occidentale. Paris.

_ (1969): "Note preliminaire sur l'industrie de la ceramique preromaine en Tingitae (Kouass, región D'Arcila)". Karthago XV. Paris.

- (1988): Aceite de oliva y salazones de pescado. Factores geoeconómicos de Bética y Tingitania. Madrid. - (1975): "Perennité des relatións dans le circuit du Détroit de Gibraltar." A.N.R.W., II, 3. Berlín- N. York. RAMÓN, J. (1981): La producción anfórica púnico-ebusitana. Ibiza.

(1981 a): "Ibiza y la circulación de ánforas fenicias y púnicas en el Mediterráneo Occidental". Trabajos del M.A.I. nํㅜ 5. Ibiza.

— (1983): “Sobre las ánforas tipo Mañá D y su proyección hacia el occidente Mediterráneo”. XVI Congr. Nac. Arqueología.

(1985): "Tagomago 1: un pecio fenicio del siglo V a.C. en aguas de Ibiza".VI Congres. Inter. De Arqueología Submarina. Cartagena. Madrid.

(1986-89): "El tipo B en la clasificación de ánforas púnicas de José Maa. Mañá”. Empuries 48-50. Barcelona.

(1991): "Las ánforas púnicas de Ibiza". Trabajos del M.A.I. nำ23. Ibiza.

(1995): "Las ánforas fenicio-púnicas del Mediterráneo Central y Occidental." Instrumenta 2. Barcelona.

RIBERA, A., (1982): Las ánforas prerromanas en el País Valenciano. Valencia.

RUIZ, J.A., (1987): "Sondeos arqueológicos de urgencia para la delimitación de las factorías de salazones "púnico-gaditanas de El Puerto de Santa María (Cádiz)." AAA'86. Sevilla.

RUIZ, D., (1986): "Castillo de Doña Blanca (Puerto de Santa María. Prov. Cádiz). Stratigraphische untersuchung einer orientalisierenden Ausiedlung." Madrider Mitteilungen 27.

SANDRO, N.di, (1986): "Le anfore arcaiche dallo Scario Gosetti, Pithecusa." Cahiers des amphores archaïques et classiques, 2.

SANMARTÍ, E., (1985): "Sobre un nuevo tipo de ánfora de época republicana de origen presumiblemente hispánico." Ceramiques greques i hellenistíques á la Península Ibèrica . Barcelona.

WILLIAMS, CH.K., (1979): "Corinth 1978: Forum Southwest." Hesperia 48.

WYLDE,H., KATZEV, M.L., (1973): "The Kyrenia ship-wreck: a fourth-century B.C. Greck merchant ship." Marine Archaelogy. Londres. 


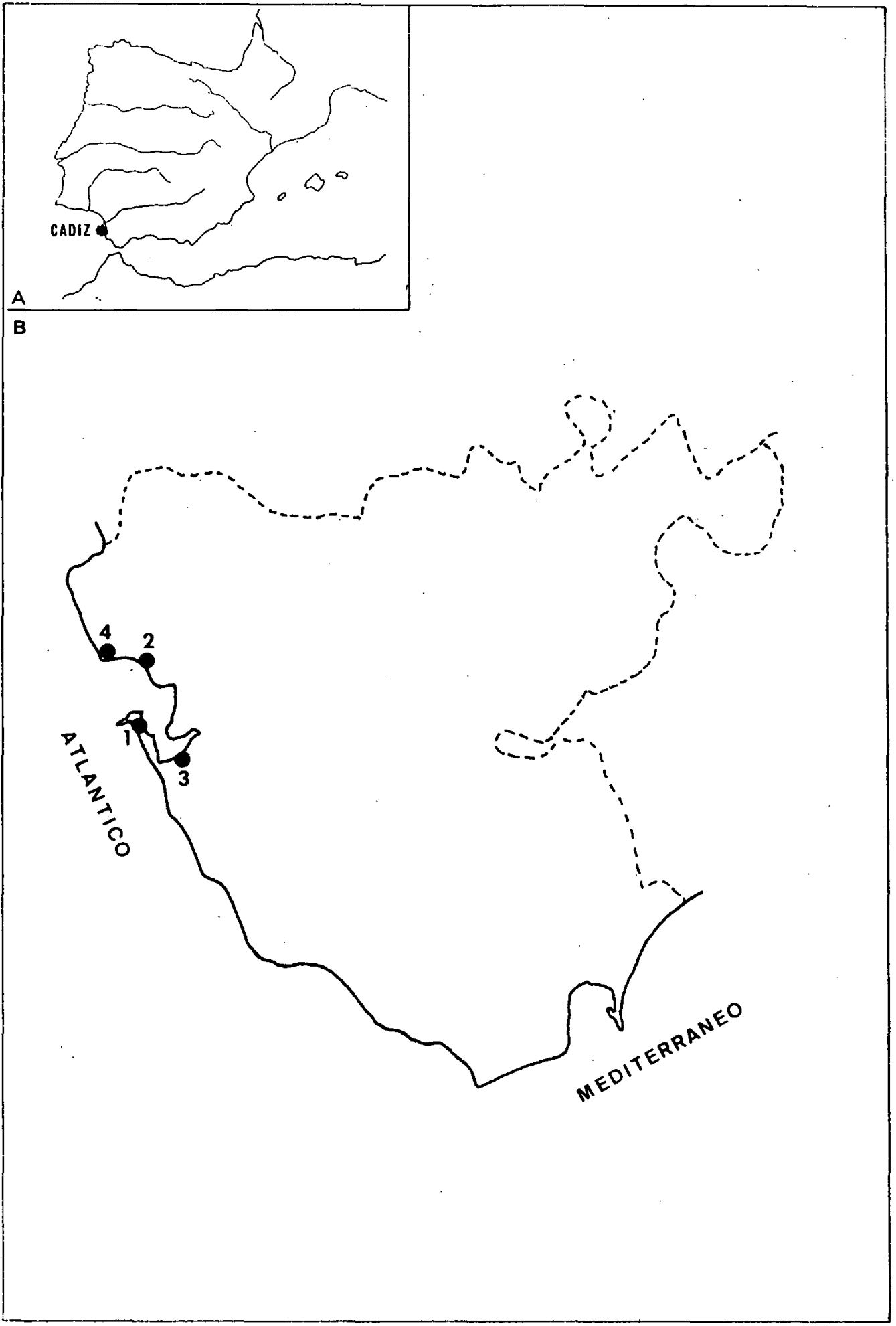

Figura 1.- Mapa de distribución de factorías de salazones y alfarerías prerromanas en la provincia de Cádiz: 1) Cádiz;2) Las Redes (El Puerto de Santa María); 3) Torre Alta (San Fernando); 4) Puntilla del Salado (Rota). 


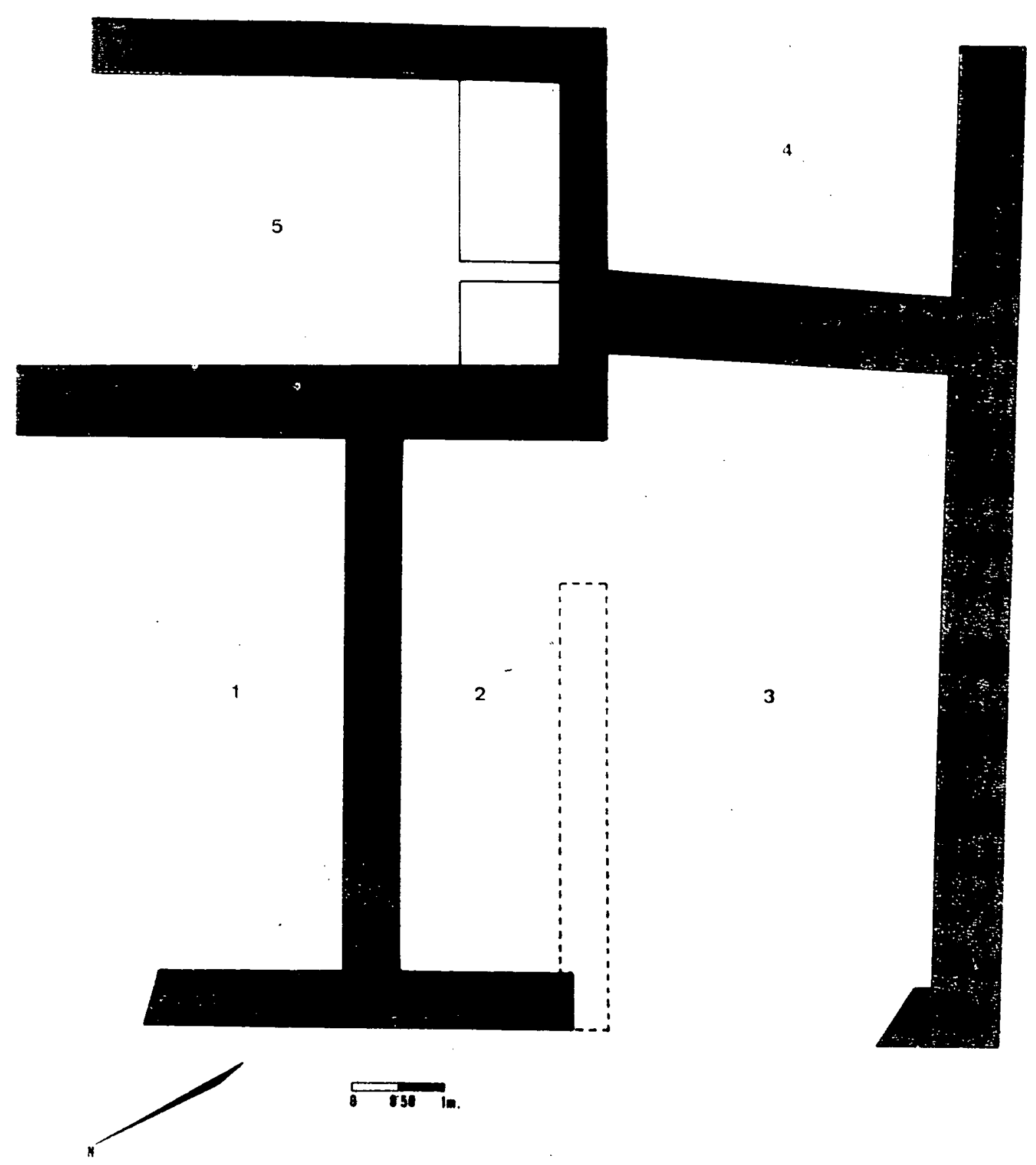

Figura 2.- Plano de planta de la factoría de salazones de Las Redes (El Puerto de Santa María). 

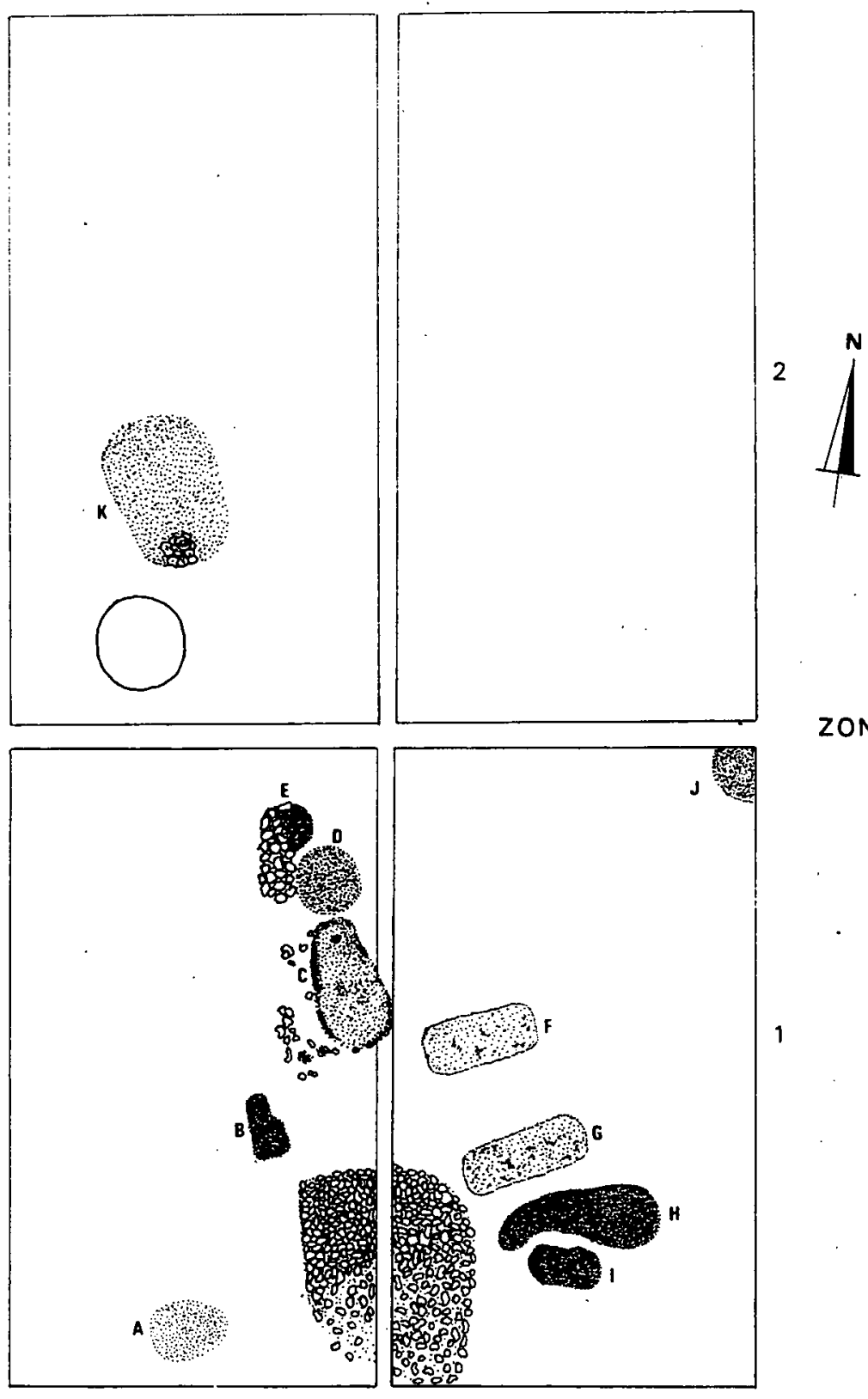

ZONA F

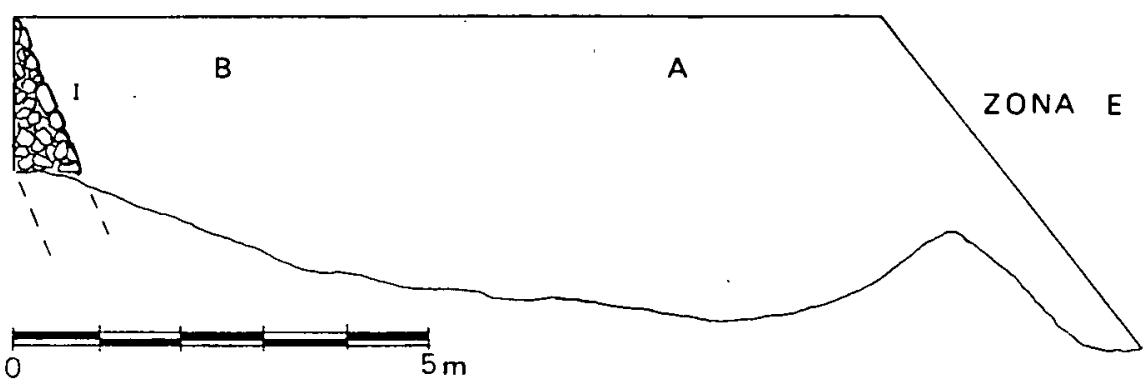

Figura 3.- Plano de planta de las estructuras de la factoría de salazones de la Plaza de Asdrúbal (Cádiz).

ISSN: 1133-4525 ISSN-e: 2255-3924

SPAL 5 (1996)

http://dx.doi.org/10.12795/spal.1996.i5.07 


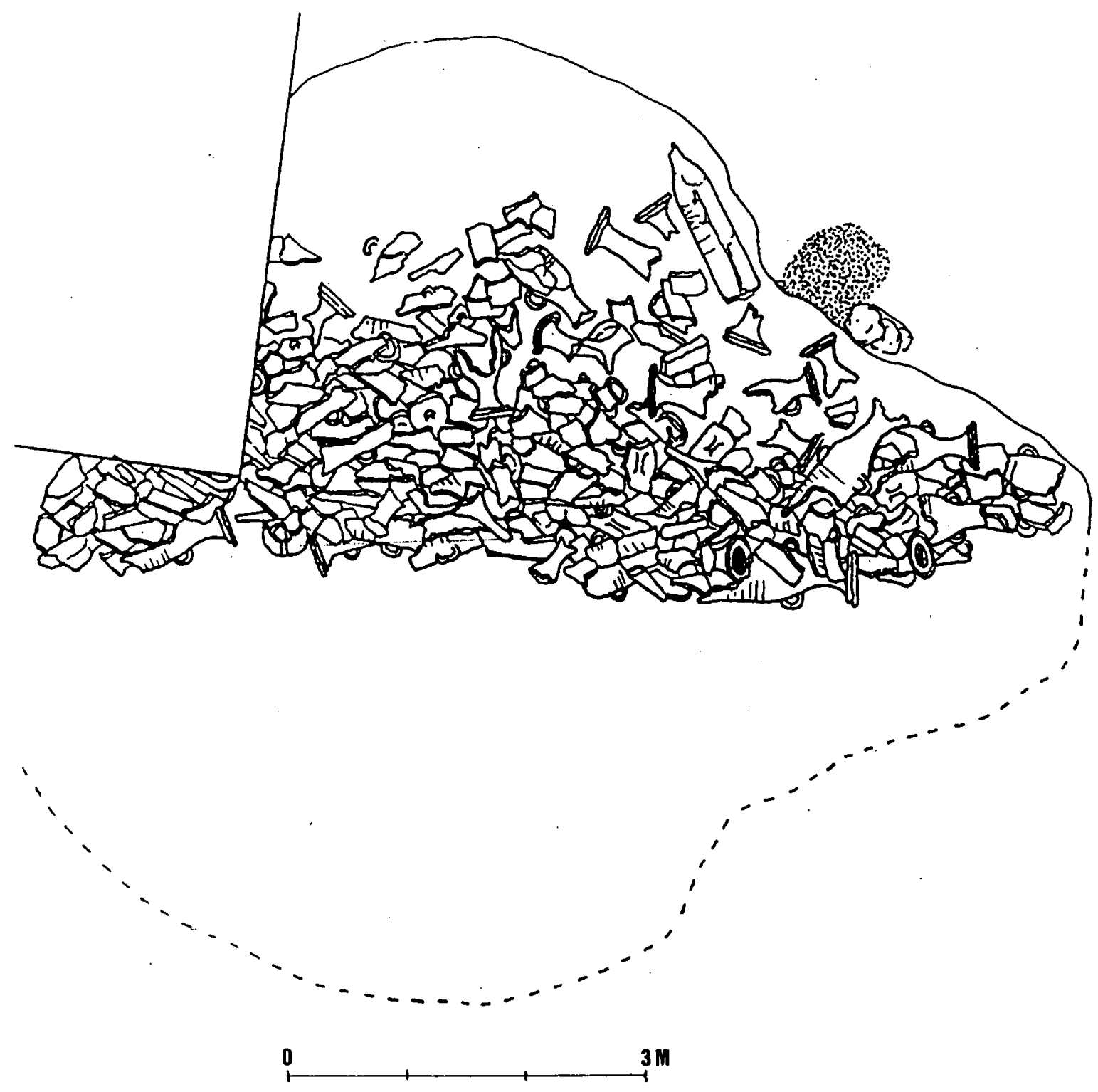

Figura 4.- Plano de planta de la zona del vertedero de ánforas de la c/ Doctor Gregorio Marañón (Cádiz). 


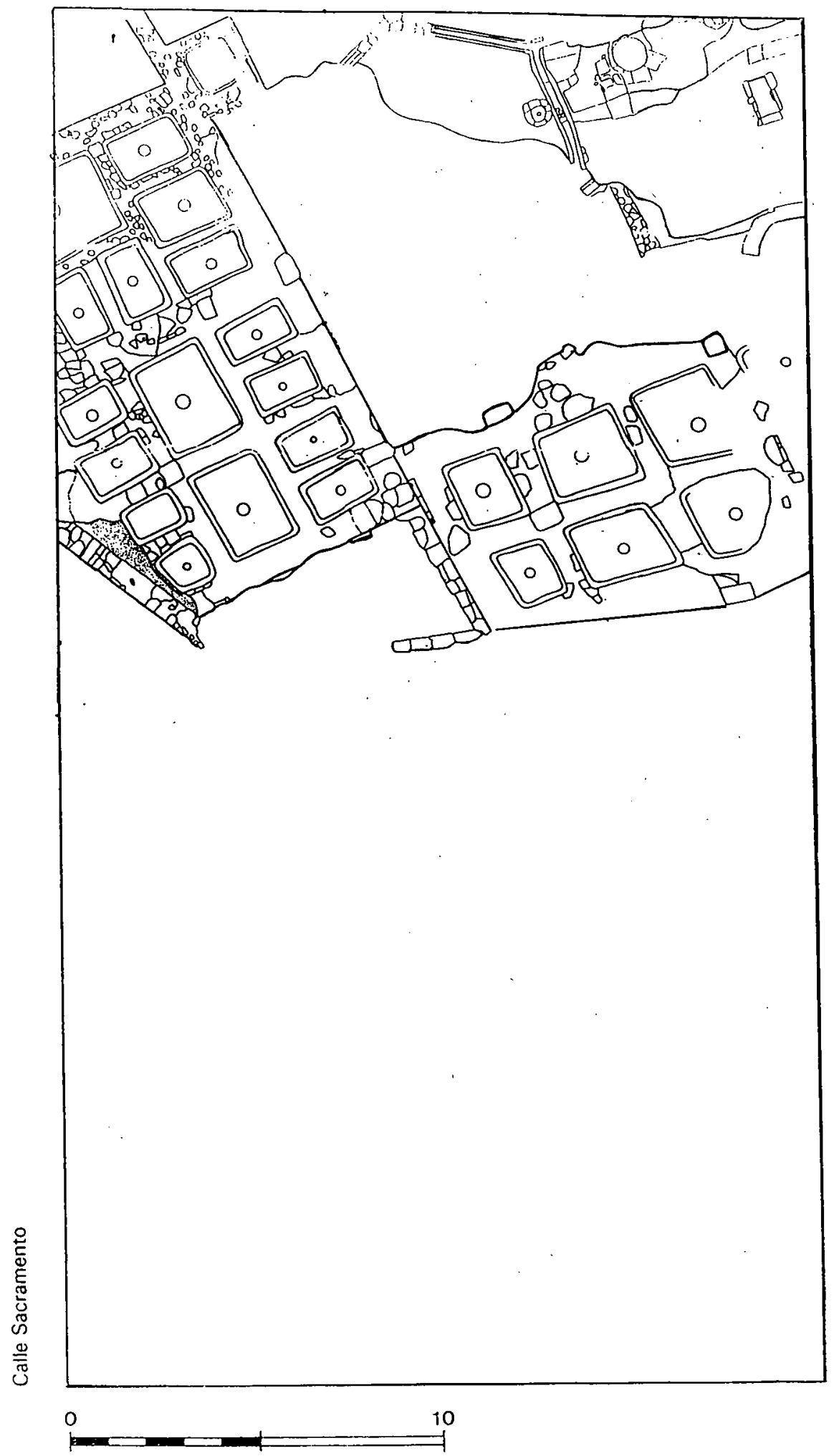

Figura 5.- Plano de planta de la factoría de salazones romana del antiguo Teatro de Andalucía (Cádiz) según L. Cobos. 

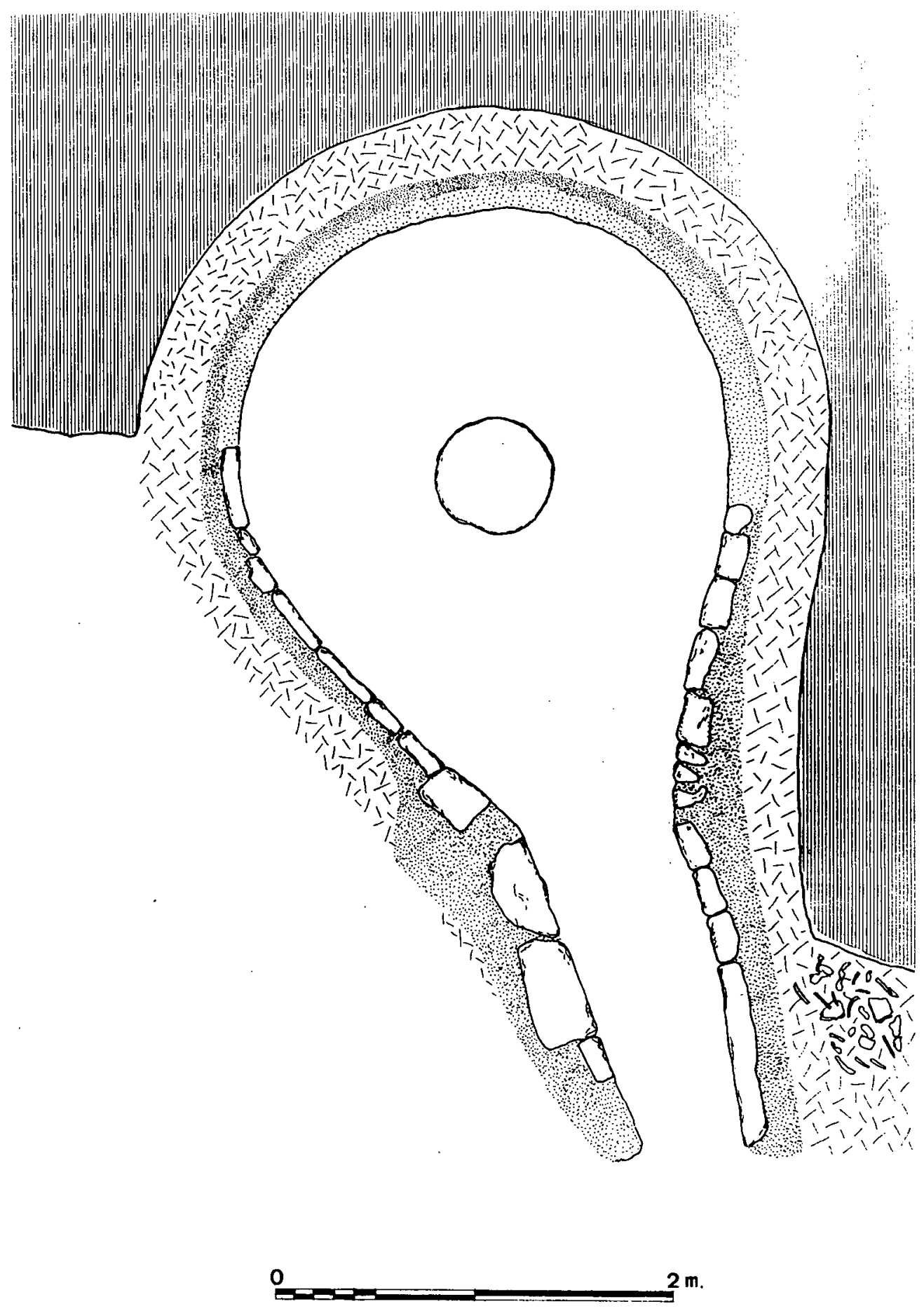

BL/88 HORNO i. Planta

Figura 6.- Plano de planta del horno I de Torre Alta (San Fernando). 


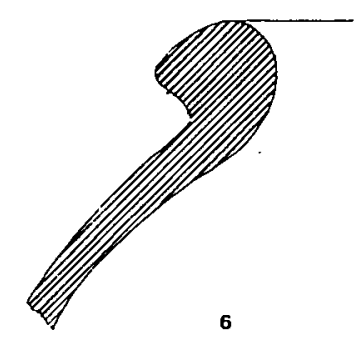

A

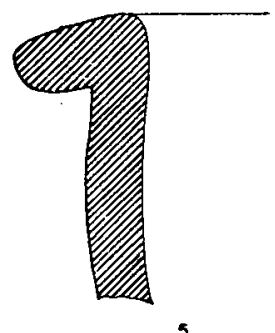

5
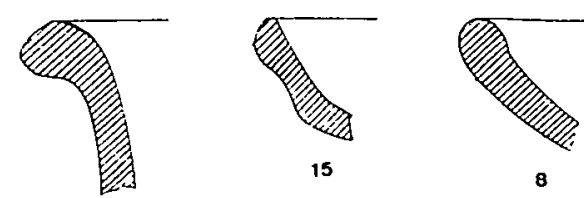
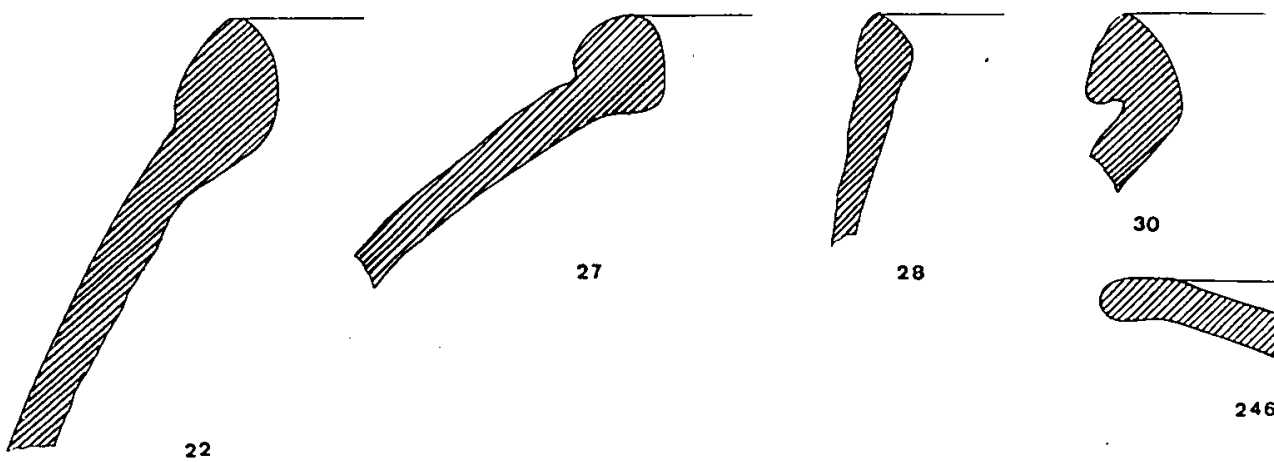

28

30

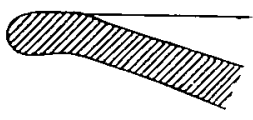

246
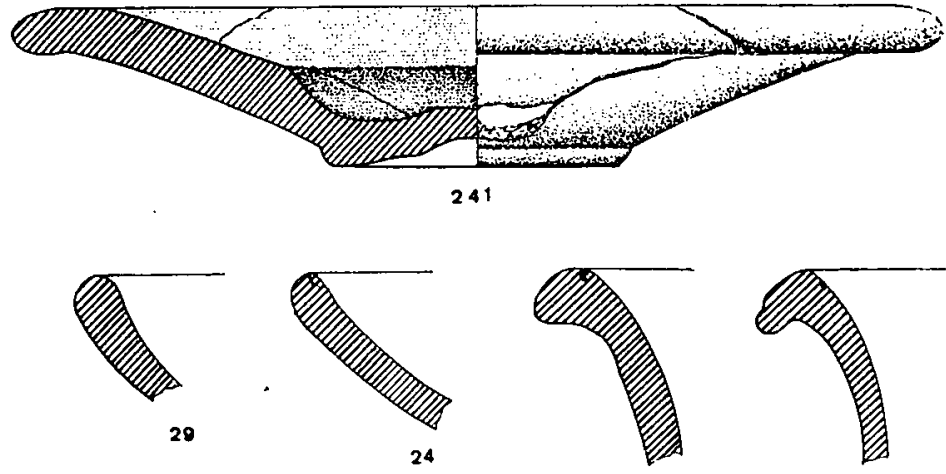

170

169

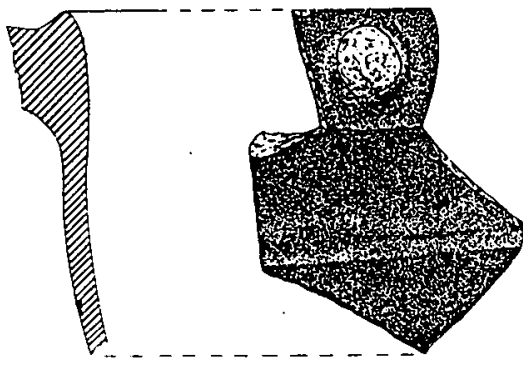

21

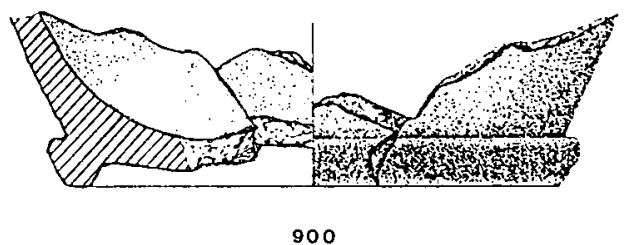

8

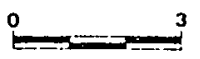

Figura 7.- Materiales cerámicos de la factoría de la Plaza de Asdrúbal (Cádiz): A) cerámicas del vertedero I; B) cerámicas del vertedero $\mathrm{H}, \mathrm{n}-21$ y 900 borde y pie de skyphos de barniz negro del siglo $\mathrm{V}$ a.C. 

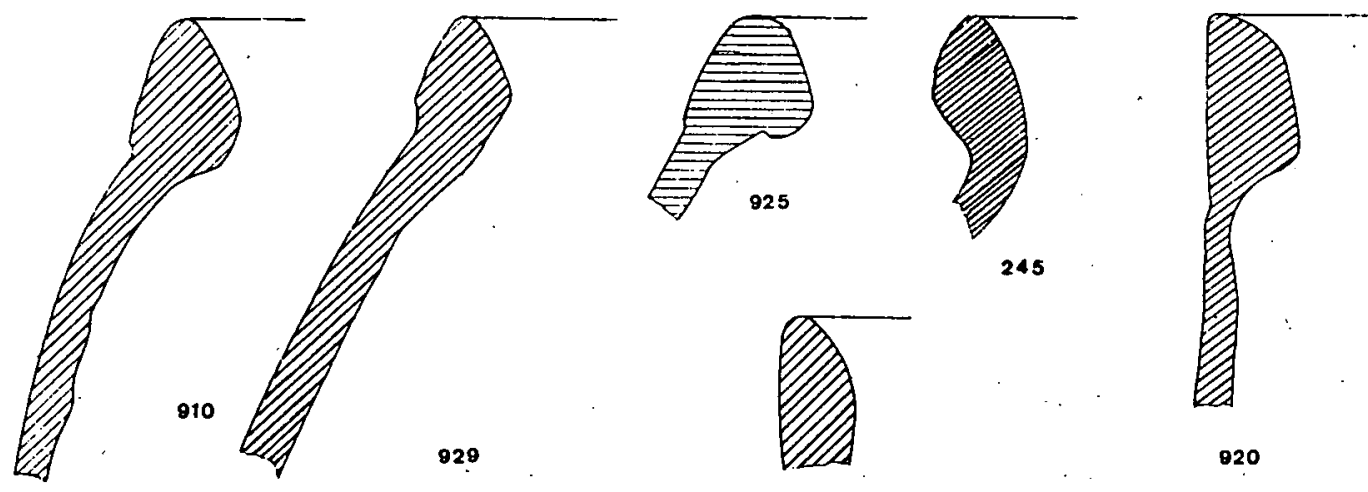

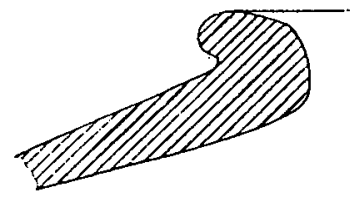

938

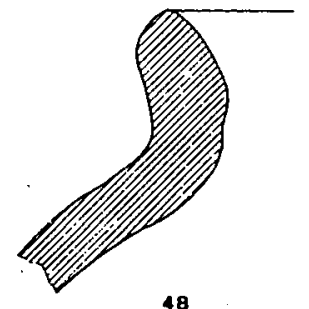

48
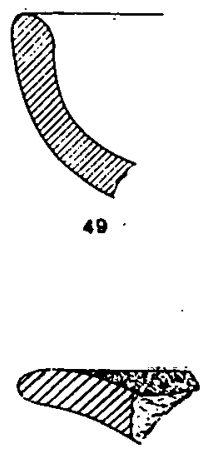

917
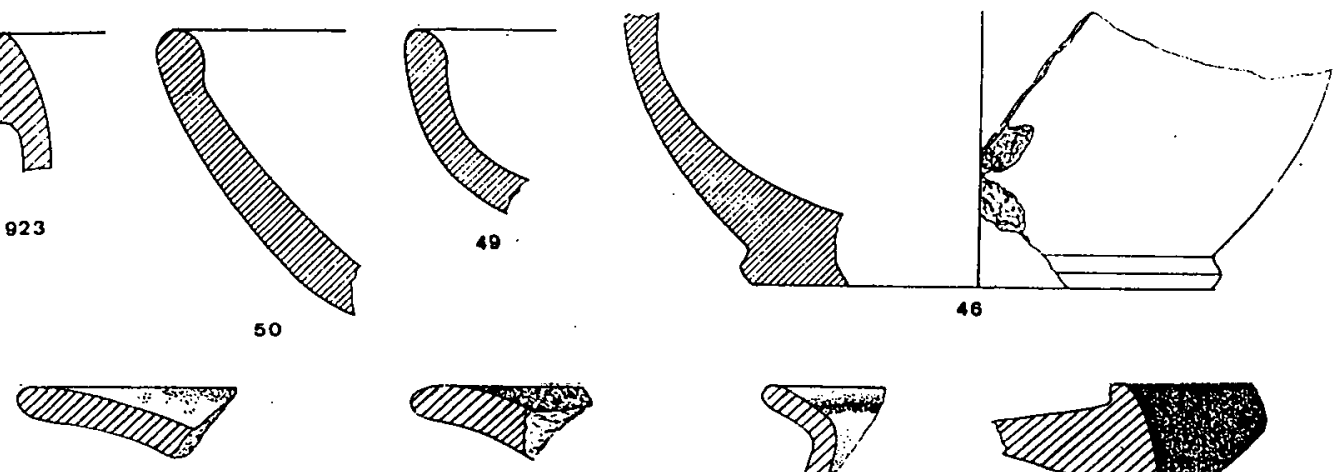

909
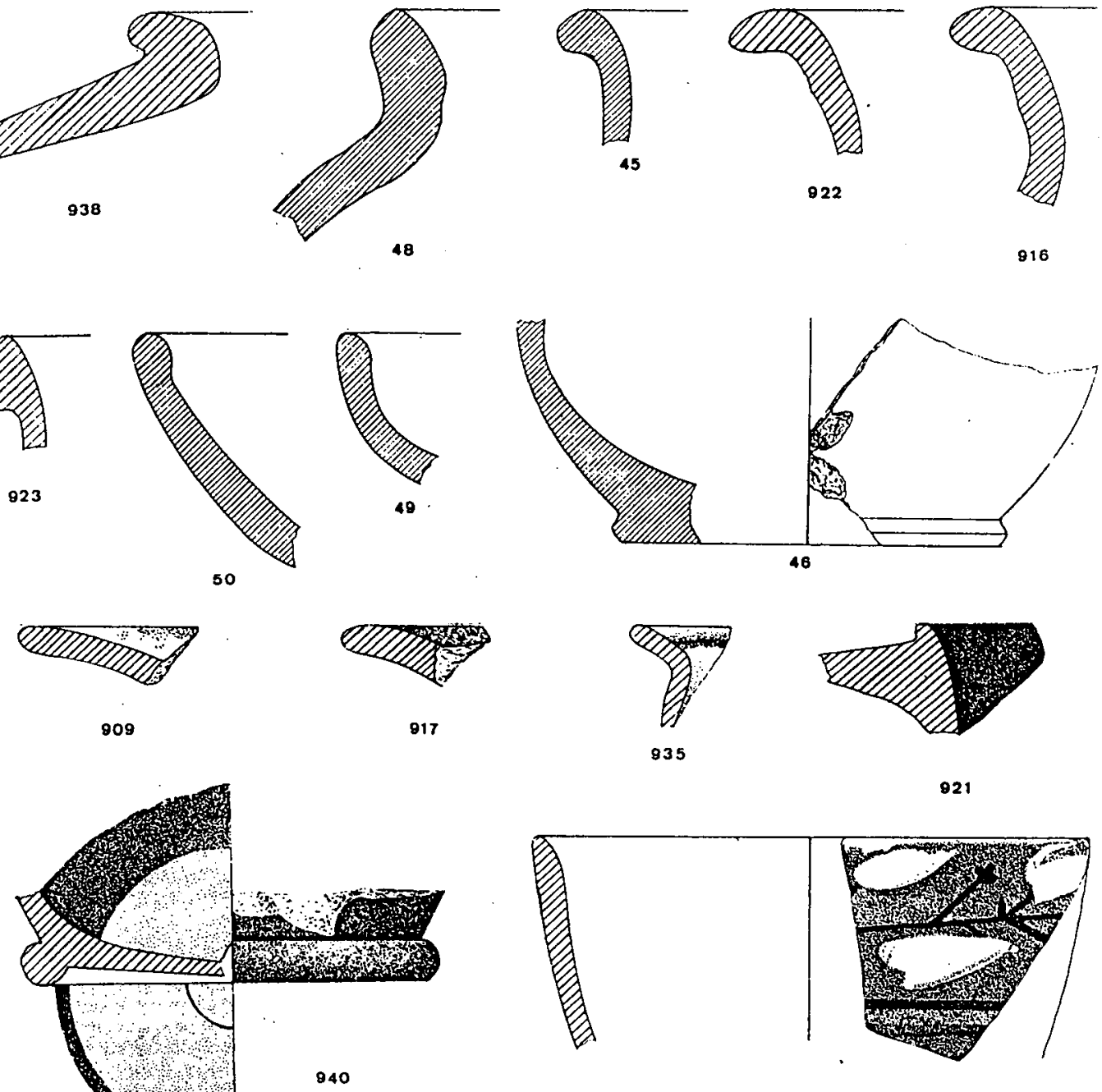

816

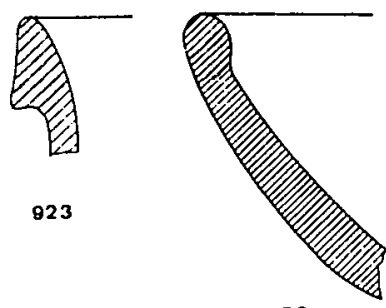

50
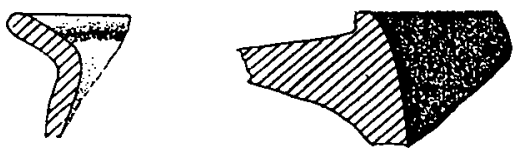

935

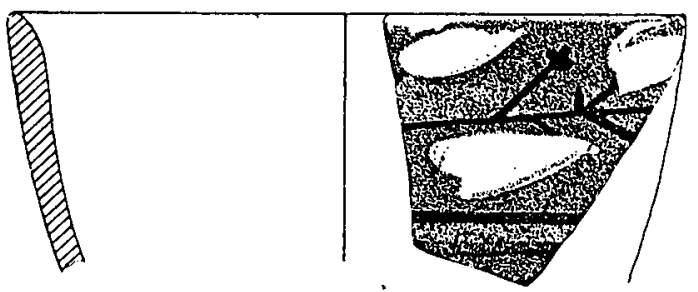

907

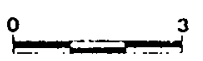

Figura 8.- Materiales cerámicos de la factoría de salazones de la Plaza de Asdrúbal (Cádiz): cerámicas del nivel 2. №907 skyphos con guirnalda de hoja de mirto de finales del siglo $\mathrm{V}$ a.C. 


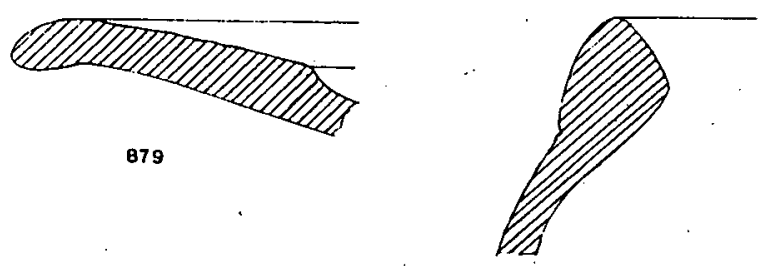

880

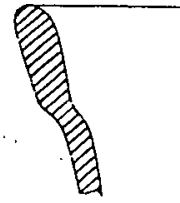

881

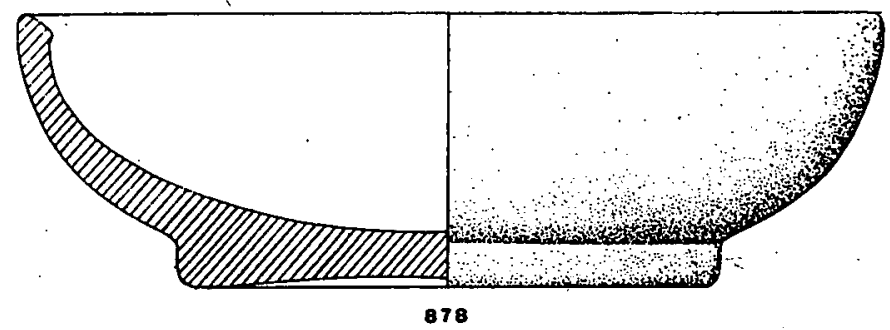

A

B.

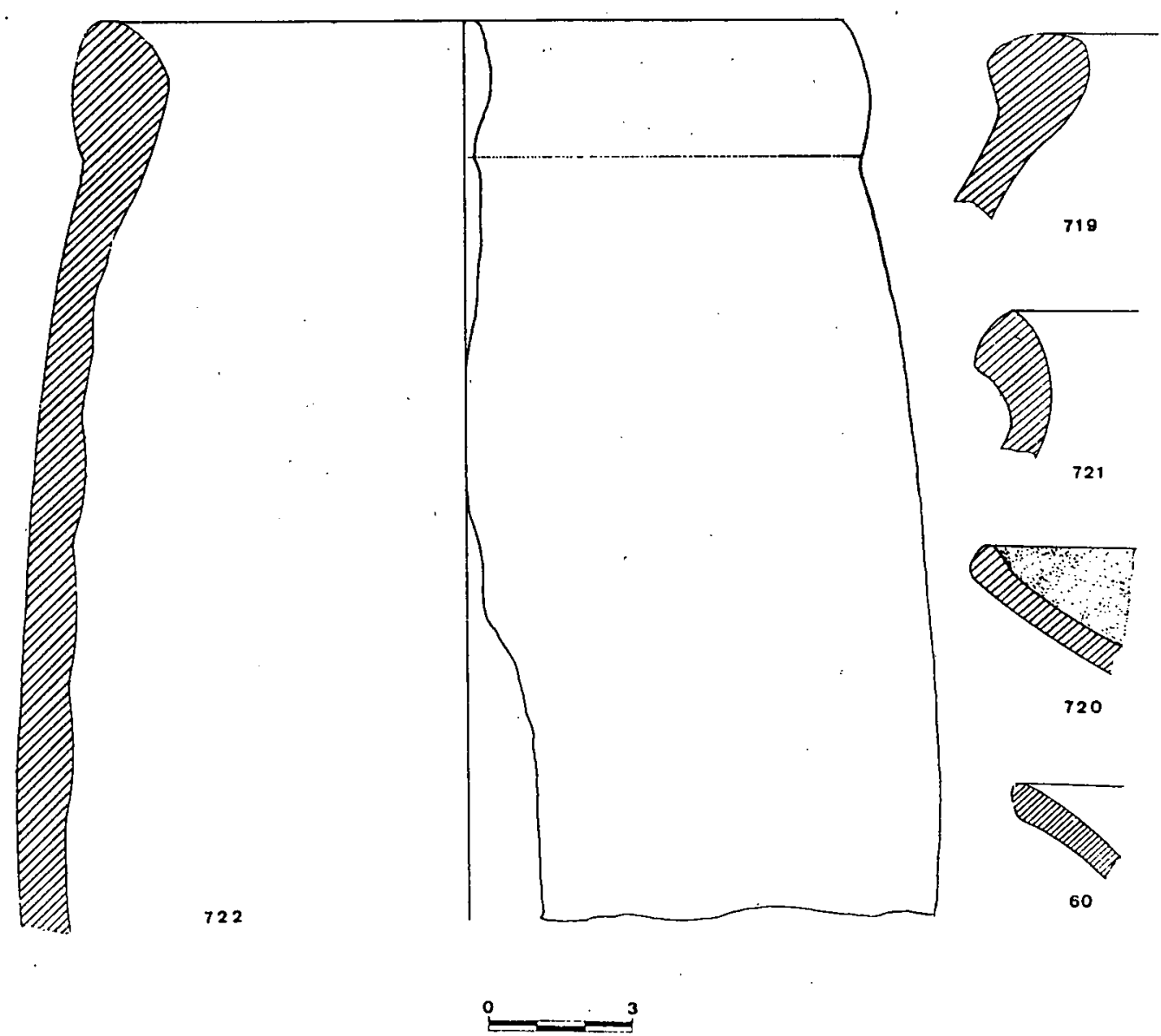

Figura 9.- Materiales cerámicos de la factoría de la Plaza de Asdrúbal (Cádiz): A) cerámicas del vertedero E; B) Cerámicas del vertedero $\mathrm{C}$. 

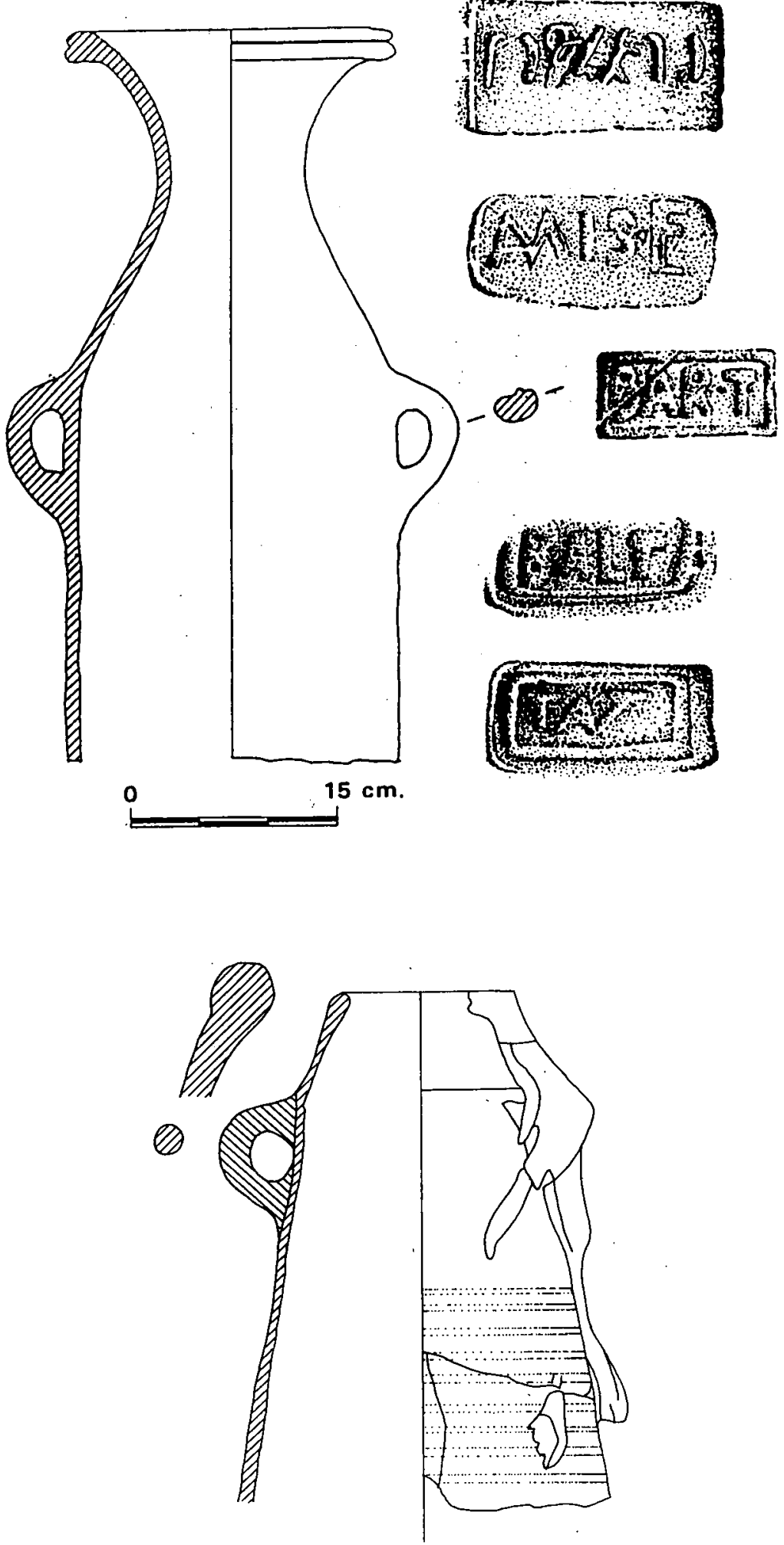

Figura 10.- A) Estampillas sobre ánforas F1 de la factoría de la c/Doctor Gregorio Marañón (Cádiz); B) Tercio superior de ánfora A4 c-e con fallos de cocción del alfar de la c/ Tolosa Latour (Cádiz). 


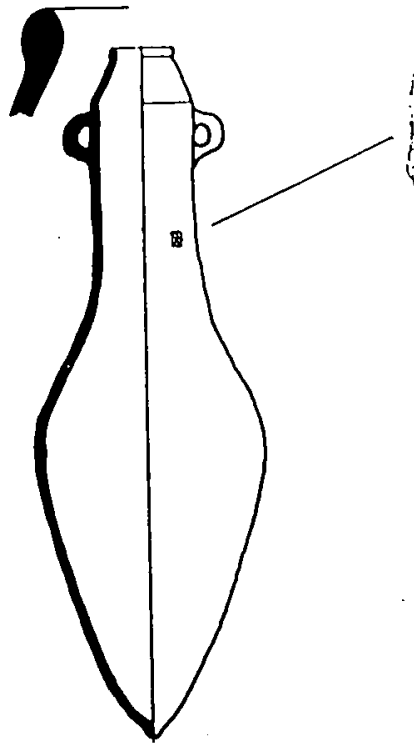

FORMA 1 A
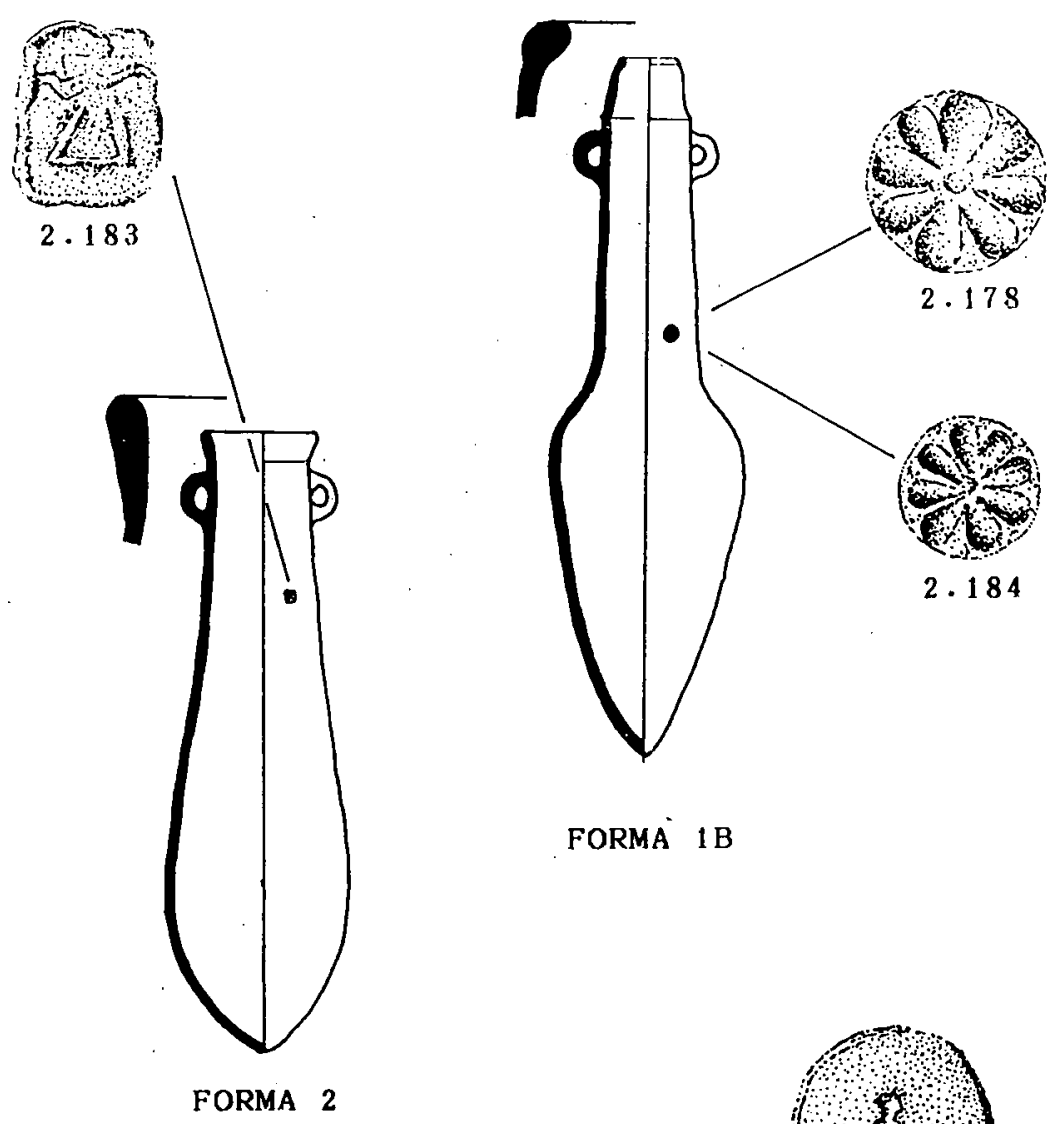

FORMAं $1 \mathrm{~B}$

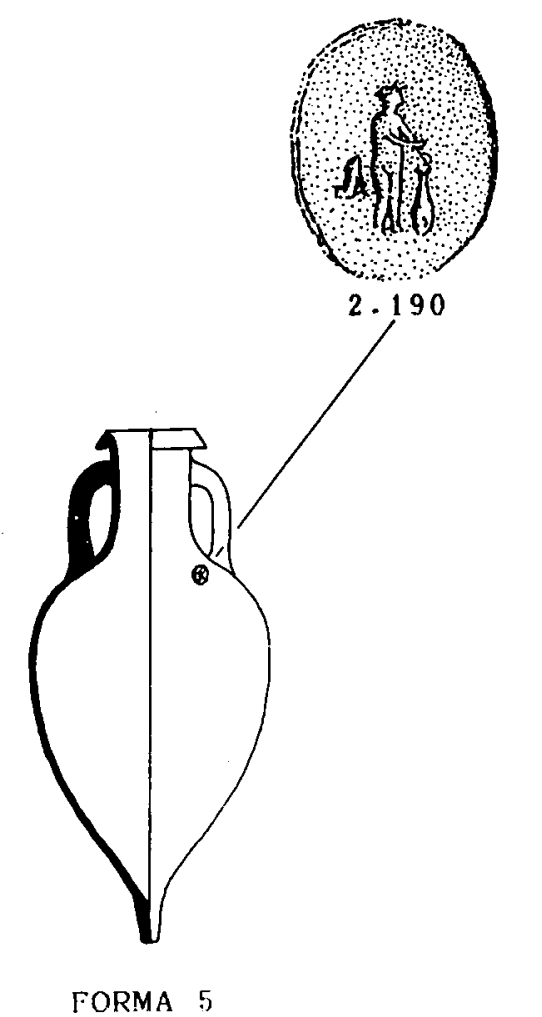

Figura 11.-Tabla de formas de ánforas fabricadas en el alfar de Torre Alta (San Fernando) y sus correspondientes estampillas. 
164

GREGORIO DE FRUTOS REYES y ÁNGEL MUÑOZ VICENTE
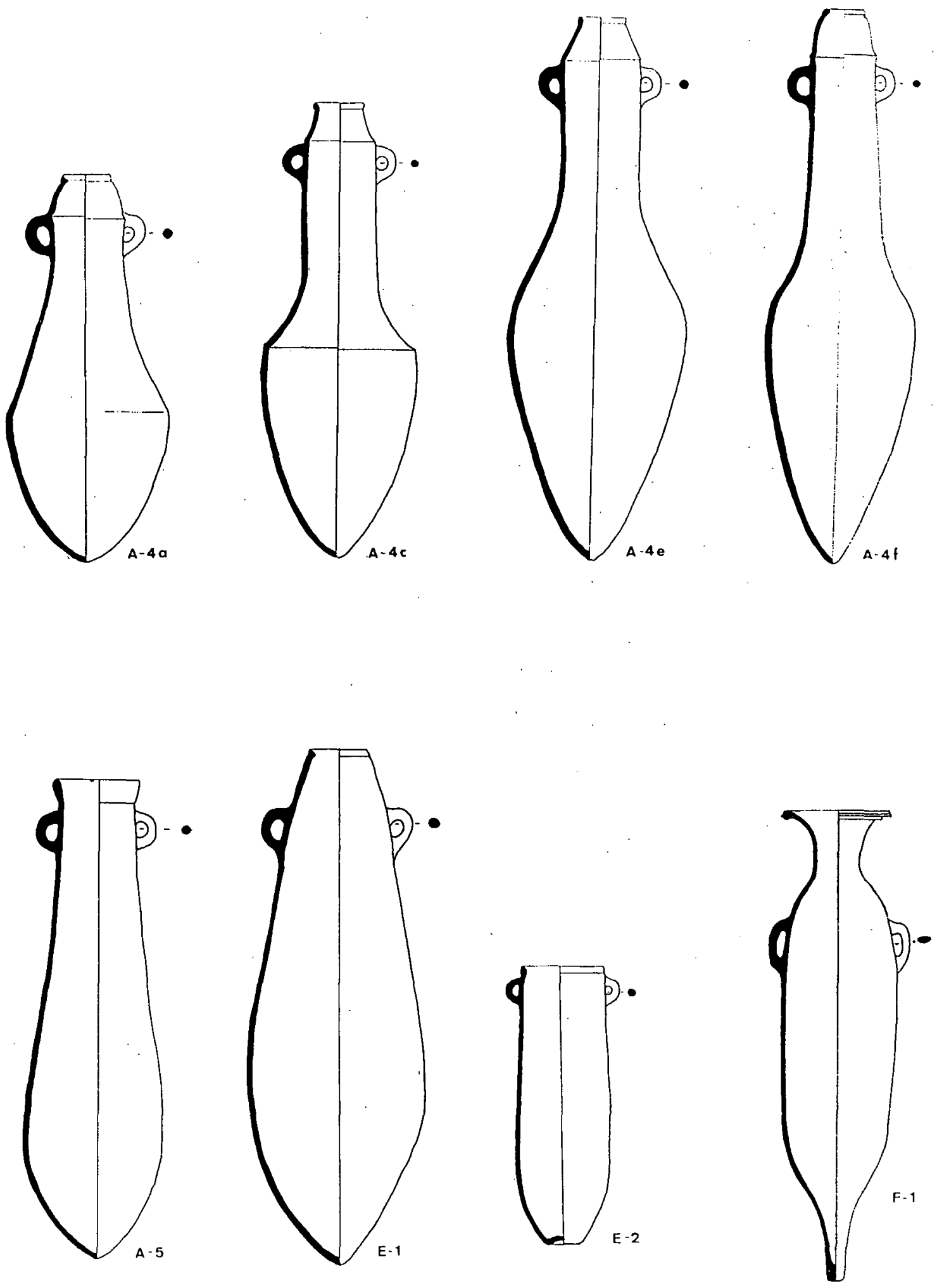

Figura 12.- Tabla de formas de ánforas púnicas producidas en el área de la Bahía de Cádiz.

SPAL 5 (1996)

ISSN: 1133-4525 ISSN-e: 2255-3924 http://dx.doi.org/10.12795/spal.1996.i5.07 

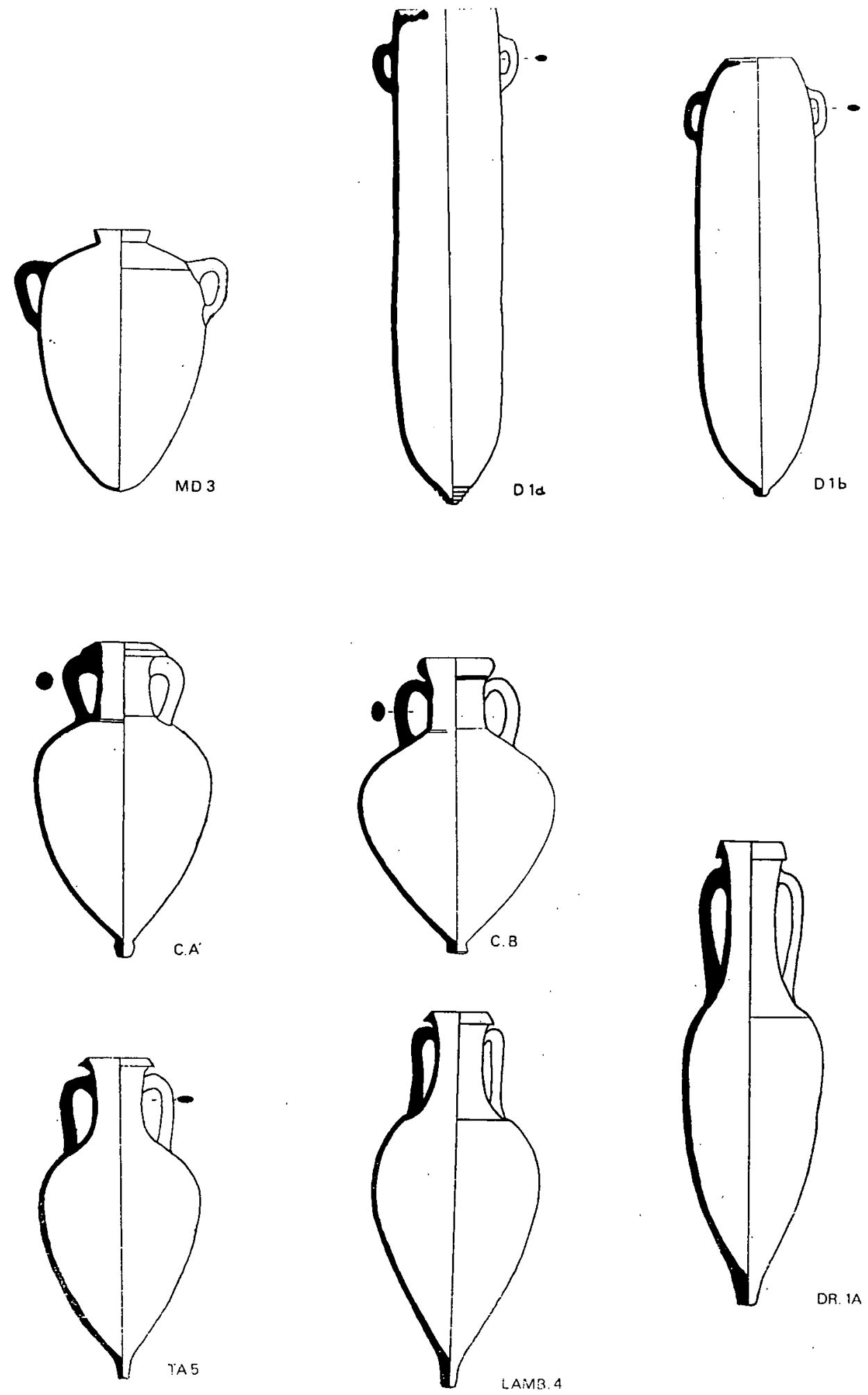

Figura 13.- Tabla de formas de ánforas importadas del Mediterráneo Central (MD3, D1 a, D1b); griegas (C.A', C.B.); grecoitálica (Lamb.4); grecoitálica fabricada en Torre Alta (TA5), e itálica (DR 1A). 